


\title{
Organizational challenges and the institutional environment: a comparative analysis of dairy cooperatives in Kenya and Morocco
}

Giel Ton ${ }^{1}$, Nora Ourabah Haddad ${ }^{2}$, Jos Bijman ${ }^{1}$, Mohamed Sraïri ${ }^{3}$ and Patience Mshenga ${ }^{4}$

\author{
1 Wageningen University \& Research \\ 2 Food and Agriculture Organization of the United Nations \\ 3 Institut Agronomique et Vétérinaire Hassan II in Rabat \\ 4 Egerton University in Nakuru
}

The research is a collaborative effort between the Food and Agriculture Organization of the United Nations and Wageningen University \& Research. The work of Patience Mshenga and Jos Bijman was co-funded by NWOWOTRO, under the Food and Business Global Challenges Programme (contract: W08.250.204).

Wageningen University \& Research

Wageningen, December 2016

REPORT

2016-088

ISBN 978-94-6343-031-9 (WUR)

ISBN 978-92-5-109579-9 (FAO) 
Ton, Giel, Nora Ourabah Haddad, J os Bijman, Mohamed Sraïri and Patience Mshenga, 2016. Organizational challenges and the institutional environment: a comparative analysis of dairy cooperatives in Kenya and Morocco. Wageningen, Wageningen University \& Research and Food and Agriculture Organization of the United Nations, Report 2016-088. 42 pp.; 3 fig.; 7 tab.; 41 ref.

This study analyses the relationship between dairy cooperatives in Kenya and Morocco and their institutional environments. It compares ten Moroccan and Kenyan dairy marketing cooperatives and suggests possible development strategies, support programmes and enabling policies in order to address two important organizational challenges, namely effective quality assurance systems and attractive and cost-efficient payment modalities for members. We discuss ways in which the institutional environment can be strengthened in overcoming these challenges, by looking into three areas: internal organizational strengthening of the cooperative sector, public support with conducive policies and regulations, and the facilitation of multi-stakeholder platforms to discuss, propose and implement these policies.

\author{
Published by \\ the Food and Agriculture Organization of the United Nations \\ and \\ Wageningen University \& Research
}

This report utilises a Creative Commons Attribution NonCommercial ShareAlike 3.0 IGO license.

The designations employed and the presentation of material in this information product do not imply the expression of any opinion whatsoever on the part of the Food and Agriculture Organization of the United Nations (FAO) or Wageningen University \& Research (WUR) concerning the legal or development status of any country, territory, city or area or of its authorities, or concerning the delimitation of its frontiers or boundaries. The mention of specific companies or products of manufacturers, whether or not these have been patented, does not imply that these have been endorsed or recommended by FAO or WUR in preference to others of a similar nature that are not mentioned. The views expressed in this information product are those of the author(s) and do not necessarily reflect the views or policies of FAO or WUR.

ISBN 978-92-5-109579-9 (FAO)

(c) FAO and Wageningen University \& Research, 2017

FAO encourages the use, reproduction and dissemination of material in this information product. Except where otherwise indicated, material may be copied, downloaded and printed for private study, research and teaching purposes, or for use in non-commercial products or services, provided that appropriate acknowledgement of FAO as the source and copyright holder is given and that FAO's endorsement of users' views, products or services is not implied in any way.

FAO information products are available on the FAO website (www.fao.org/publications) and can be purchased through publications-sales@fao.org.

Wageningen University \& Research accepts no liability for any damage resulting from the use of the results of this study or the application of the advice contained in it.

Wageningen University \& Research - P.O. Box 29703, 2502 LS The Hague, The Netherlands, T +31 (0)70 33583 30, E communications.ssg@wur.nl, http://www.wur. eu/ economic-research.

This report can be downloaded for free at http://dx.doi.org/10.18174/399770 or at www. wur. eu/economic-research (under Wageningen Economic Research publications).

Report 2016-088 | Project code 2282600065

Cover photo: iLINOVA-project/Egerton University 


\section{Contents}

$\begin{array}{ll}\text { Preface } & 7\end{array}$

$\begin{array}{lr}\text { Executive summary } & 9\end{array}$

1

Introduction $\quad 11$

$\begin{array}{lll}1.1 & \text { Conceptual framework } & 11\end{array}$

$\begin{array}{lll}1.2 & \text { Research methodology } & 13\end{array}$

2

Organizational and institutional challenges for Kenyan dairy cooperatives 16

2.1 Institutional context 16

2.2 Organizational challenges and solutions $\quad 18$

2.3 Implications for the institutional environment 23

Organizational and institutional challenges for Moroccan dairy cooperatives 26

3.1 Institutional context 26

3.2 Organizational challenges and solutions 29

3.3 Implications for the institutional environment 32

4.1 Cooperative strengthening and self-organization $\quad 35$

4.2 Public support and regulation $\quad 36$

$\begin{array}{lll}4.3 & \text { Public-private policy dialogues } & 37\end{array}$

4.4 Recommendations for an enabling institutional environment 37

References and websites 



\section{Preface}

Evidence from research and experience shows that cooperatives - and similar forms of producer organizations - can help small and family farmers capture a higher share of the value added in the food chain. These organizations create bargaining power and economies of scale for their members. They also reduce market risks and transaction costs, provide access to productive resources, and enable their members to influence policy-making processes. For downstream private enterprises in the food chain, cooperatives play an essential role as aggregators, in securing quality and timely supply of agricultural products. In addition, cooperatives provide inputs and technical advice to member smallholders. Thus, agricultural cooperatives offer a wide range of services to their members and other actors in the food chain and at the same time play a key role in achieving food security and contributing to rural development.

Agricultural cooperatives operate in a rapidly changing environment, characterized by globalized agricultural markets and liberalization, climate change and food insecurity, and changing consumer demands. Therefore, agricultural cooperatives have to continuously adapt to the changing economic and institutional environment, competing and interacting with other types of enterprises, while trying to maintain their specific identity as social and economic organizations.

The changing environment also creates new challenges for policymakers. The agricultural cooperative of the future has other demands as to the institutional environment, if it wants to remain competitive and sustainable. It is therefore essential to fully understand the factors related to the institutional environment that influence the performance and sustainability of cooperatives. Increased understanding of the realities and challenges will provide insights for a supportive institutional environment that may lead to conducive public policy and well-targeted development support.

The present study focuses on dairy cooperatives in Kenya and Morocco, to explore how and to what extent the institutional environment has been enabling the development and performance of the cooperatives. The focus on dairy generates insights that are relevant for many countries, because it is a sector in which cooperatives have a relatively high market share. Kenya and Morocco are especially interesting cases because they are both large milk producers, among the top-10 in Africa. The study zooms in on two key challenges for the cooperatives and their options for finding appropriate solutions: systems to assure the quality of the milk, and methods to offer attractive payments to the farmers.

The study was carried led by Wageningen Economic Research, by assignment of - and in close collaboration with - the team Producer Organizations and Cooperatives of FAO. The authors express their gratitude and acknowledgement to the representatives of the cooperatives and professional associations in Kenya and Morocco, who were so kind as to share their time, views and experience with the research team.

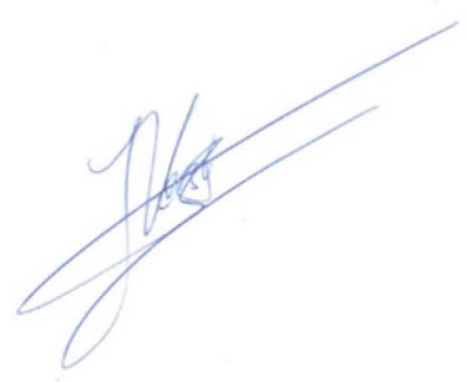

Prof.dr.ir. J.G.A.J . van der Vorst General Director Social Sciences Group Wageningen University \& Research

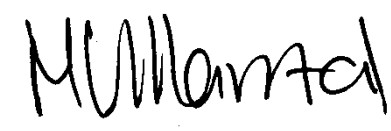

Dr. Marcela Villarreal

Director of Partnerships, Advocacy and Capacity

Development Division

Food and Agriculture Organization of the United Nations 


\section{Executive summary}

This study analyses the relationship between selected dairy cooperatives in Kenya and Morocco and the institutional environment. It compares ten Moroccan and Kenyan dairy marketing cooperatives and suggests possible development strategies, support programmes and enabling policies in order to address two main organizational challenges, namely quality assurance systems to deliver quality milk to the processing industry, and attractive and cost-efficient payment modalities for members. We discuss ways in which the institutional environment can be strengthened to support dairy cooperatives in overcoming these challenges, by looking into three areas: internal organizational strengthening of the cooperative sector, public support including conducive policies and regulations, and the facilitation of multi-stakeholder platforms to discuss, propose and implement enabling policies.

\section{Dairy cooperatives need a more enabling institutional environment}

The study shows a remarkably different picture of dairy cooperatives in Kenya and Morocco. In Kenya, the first-tier, primary collection cooperatives resemble the archetypical multi-purpose cooperative, with multiple services to members that create commitment and supply loyalty. In Kenya, the cooperative sector collects only milk from members. In Morocco, the primary cooperatives are different from the archetypical cooperative, because they may include members that function as 'peddlers' to collect milk from other non-member farmers in addition to their own supply. Primary cooperatives buy a substantial part of the milk from informal peddlers. This practice limits traceability and quality control, and weakens the loyalty of farmers to their cooperative and their willingness to invest in collective action.

Both countries show similarities in the development of their institutional context, with high state involvement in the 1960-70s, which was gradually replaced by an increased role for private investments in processing in the 1980s, followed by a phase of liberalization with unregulated dairy prices from the 1990 onwards. The study shows that both in Kenya and in Morocco, the institutional environment can be improved in order to facilitate the development of cooperatives and to increase their possibilities to find efficient solutions for the organizational challenges related to quality improvement and member payment. From our exploration it became clear that developing and implementing quality testing systems are typically the tasks of public-private partnerships, as state regulation and financial support must go hand-in-hand with strict agreements both among cooperatives and between cooperatives and private milk processors.

In Kenya, the cooperative sector is based on a strong network of first- and second-tier cooperatives, which have developed links with the private sector and policy making processes, including an active coordinating role for the Kenyan Dairy Board. In Morocco, the links between dairy cooperatives, dairy processing companies and the government have only recently started to materialize. A promising development is the recent establishment of the interprofessional platform, FIMALAIT, to design appropriate dairy policies, and act as a mobiliser of investment support to address the milk quality challenges. In the end, good collaboration among the state, farmer organizations, private companies and NGOs, could lead to a more "pro-active role in overcoming market constraints to achieve pro-poor agricultural growth" (Ortmann and King, 2007).

\section{Organizational challenges are inherent to collective marketing}

In their ambition to be effective marketing organizations for their members, cooperatives face several organizational challenges. The main challenge for a cooperative is to effectively manage the tensions between individual members and the cooperative. The individual member has an interest in reducing effort (and thus costs) in reaching a certain product quality level, while the cooperative has an interest in receiving products that have the agreed quality level, as that directly relates to efficiency in processing and marketing. Internal regulations on quality can help to solve this problem. However, internal regulations do not work effectively in situations where quality cannot easily (i.e. against low cost) be measured and in situations where farmers have alternative sales options that do not require good quality milk. In both Kenya and Morocco, the dairy cooperatives found various ways to resolve these agency dilemmas. 


\section{Policy recommendations}

In both countries, the changes in the dairy landscape following the liberalization of the dairy markets in the 1980 and 1990s represent a need and opportunity to redefine not only the roles of the various private actors but also that of the state, towards an increase in quantity and quality of milk production and a more equitable distribution of benefits along the dairy chain. The state can perform an important facilitating role by presenting a strategic vision of dairy development, stimulating the coordination among public and private actors in the dairy industry, and presenting clear regulations on milk quality and fair payment schemes.

Both quality improvement and the introduction of fair and efficient payment schemes may need closer collaboration between public and private partners in the dairy industry - not only to improve information exchange for learning purposes, but also because some regulation may be needed to help the sector solve collective action problems. These regulations may be issued by the state or by a public-private organization with sufficient authority in the industry. By facilitating the creation of a platform for professional organizations and agricultural cooperatives to discuss policies, the government can support the development of much-needed networking and collaboration.

The state can induce dairy processors to pay dairy cooperatives immediately upon delivery of the milk, so that the latter can promptly pay their members. The state can also facilitate the credit provisioning by banks to shorten the payment period for milk supplied to the cooperatives. The state could reduce the risk that private sector banks face when dealing with dairy farmers and cooperatives by offering low-interest funds for financial products targeted to dairy development, or guarantee funds for working-capital loans to cooperatives.

\section{Case study method}

In each of the two countries, various dairy cooperatives were selected to cover a diversity of organizational forms. Information about these cooperatives was collected through in-depth interviews with each of the three different stakeholder groups: professional staff (e.g. manager and quality manager), board members (e.g. president and vice-president), and members (e.g. a small and a large dairy farmer). The interview reports were coded using qualitative coding software Atlas. $\mathrm{ti}^{\mathrm{T}}{ }^{\mathrm{m}}$, to facilitate the comparative analysis and synthesis of findings from the cooperatives within each country as well as between the two countries. The sample of cooperatives in each country did not pretend to be representative of the sector as a whole, but to be diverse enough in size, location and functions to obtain an insight into the main organizational challenges related to quality assurance, payment system and training of staff.

The Kenya case study covered six dairy cooperatives, all sourcing milk from smallholder producers, but differing in size and activities. Four of the cooperatives only functioned as bulking nodes for raw milk delivered to private processors, whereas other cooperatives had their own processing units. In Morocco, four case studies were carried out. The sample included three milk collection cooperatives and one processing cooperative. In addition, staff of two professional organizations related to the dairy chain in Morocco were interviewed.

\begin{tabular}{|c|c|c|c|c|c|}
\hline & Cooperative & $\begin{array}{l}\text { Date of } \\
\text { creation }\end{array}$ & $\begin{array}{r}\text { Initial number of } \\
\text { members }\end{array}$ & $\begin{array}{l}\text { Current number } \\
\text { of members }\end{array}$ & $\begin{array}{l}\text { Daily milk volumes } \\
\text { collected (metric tons) }\end{array}$ \\
\hline \multirow[t]{4}{*}{ KENYA } & $\begin{array}{l}\text { Githunguri Dairy } \\
\text { Farmers }\end{array}$ & 1961 & 31 & 23000 & 200.0 \\
\hline & Muki Dairy Farmers & 1989 & 9 & 15000 & 70.0 \\
\hline & Mumberes Farmers & 1960 & 74 & 3300 & 14.0 \\
\hline & Ukuu Farmers & 2000 & 150 & 700 & 1.2 \\
\hline \multirow[t]{3}{*}{ Morocco } & Colait/Extralait & 1953 & 21 & 88 & 165.0 \\
\hline & Al Mouna & 2000 & 12 & 9 & 3.7 \\
\hline & Al Badre & 2003 & 71 & 81 & 2.5 \\
\hline
\end{tabular}




\section{Introduction}

Producer organizations and agricultural cooperatives are key contributors to achieving food security and reducing hunger in the world. They provide a wide range of services to their member producers including access to output and input markets, financial services, access to and management of natural resources, as well as influence in policy-making processes. Inclusive and efficient producer organizations and agricultural cooperatives are essential for a thriving agricultural sector and for boosting rural economies, as they create jobs and help improve their members' incomes and livelihoods. In order for these organizations to perform their role as service providers and employment generators, they need an institutional environment that facilitates their establishment and development under viable conditions. The institutional environment within which producer organizations and agricultural cooperatives operate is crucial, as it has an effect on the sustainability of these organizations. Enabling institutions are, for example, transparent and sound regulatory and legal frameworks, a climate conducive to investment, as well as space for policy dialogue with the government.

Milk production is an important economic activity of millions of small farmers and landless labourers. As a highly perishable product, milk requires special and timely care. Collective action, in the form of agricultural cooperatives and other types of producer organizations ( $\mathrm{PO}$ ) is used to link smallholder farmers to processing plants (Bijman et al., 2016; Dorward et al., 2003). Agricultural cooperatives and producer organizations in the dairy sector operate within a broader economic and institutional environment. To perform well, they require an external environment that supports their organization, operations and strategies. In other words, they require an "enabling environment" that helps them to prosper.

This field study is linked to wider research on the interaction between organizational challenges in collective marketing and the institutional environment in which these cooperatives operate (Bijman et al., 2012; Bijman et al., 2016). The research is focussed on the dairy sector. Two typical organizational challenges have been selected: developing and applying an effective and efficient quality assurance system; and developing and applying a payment system that reduces financial costs and risks to the organization. The field research intends to 'ground' the analysis of policies that affect the institutional environment in the real-world practices of dairy cooperatives in two countries: Morocco and Kenya. Therefore, in each country, the institutional environment was described and several in-depth case studies of dairy cooperatives were conducted.

\subsection{Conceptual framework}

The research is centred on the capacity of dairy cooperatives to organize collective marketing to the satisfaction of both the members and the organization (Ton, 2010). This capacity is enabled or constrained by an external environment. A dairy cooperative operates within a particular context and results in certain outcomes (costs and benefits) (Figure 1 ). To perform well, the cooperative needs to develop and apply effective systems for quality assurance, payment and Human Resource Management (HRM). Organizational capacities result from social capital that is created when individuals "spend time and energy working with other individuals to find better ways of making possible the achievement of certain ends that in its absence would not be possible" (Ostrom, 1996). Producer organizations and agricultural cooperatives are organizational expressions of this social capital (Herbel and Ourabah Haddad, 2012).

We focussed the study especially on the influence that institutions have on the marketing capacity of agricultural cooperatives and producer organizations. These organizations try to adapt to the institutional environment to better suit their needs (Herbel and Ourabah Haddad, 2012), and/or strategically use policies or regulations in a way that create most benefit for the cooperative (Mendoza 
and Ton, 2003). The institutional environment becomes enabling when there are transparent and sound regulatory and legal frameworks (World Bank, 2012), enabling policies (Agarwal, 2001; Penrose-Buckley, 2007; Markelova and Mwangi, 2010), a climate conducive to investment through incentives and other support services (Gijselinckx and Bussels, 2014), and spaces for policy dialogue, allowing social capital development (Coleman, 1988). Well-designed institutions are key requirements to make markets function for the poor, (Dorward et al., 2003; Biénabe and Sautier, 2005). Institutions are seen as the "rules of the game" (North, 1990) that define the room for cooperative problem-solving and development. Dairy cooperatives benefit from institutions that support collaboration, induce trust and long-term commitment and foster transparency. In addition, formal institutions such as regulations can help to clarify the rights and obligations of the various stakeholders, and can provide legitimacy to the collective actions of the organizations (Agarwal, 2001; Thorp et al., 2005).

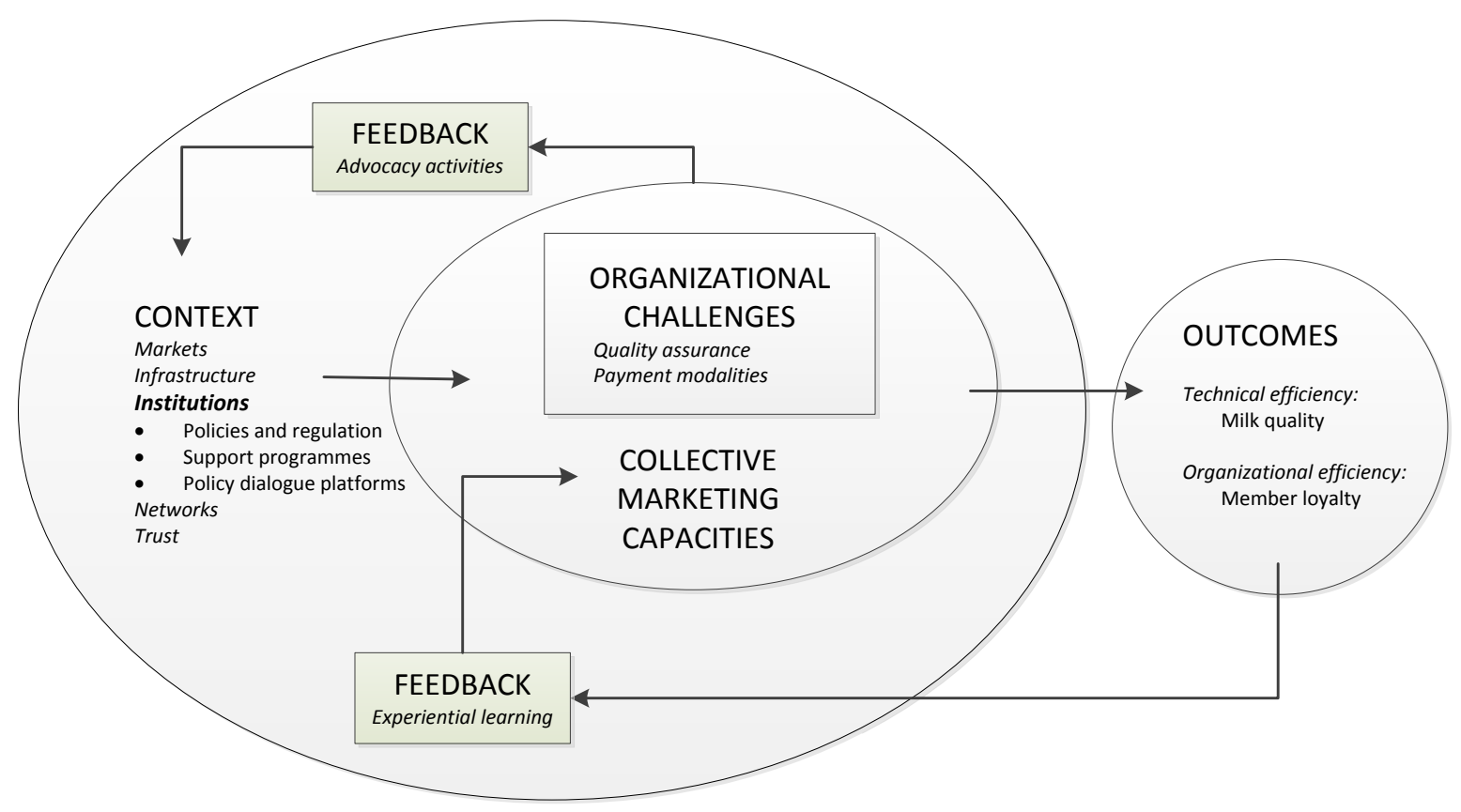

Figure 1 Conceptual framework for the analysis of organizational challenges in collective marketing, based on Ton (2015)

A dairy cooperative operates in an institutional context that affects certain outcomes related to technical and organizational efficiency (see Figure 1). The institutional context consists of markets, infrastructures, institutions per se, networks and trust (Leana and Van Buren, 1999; Ostrom and Ahn, 2009). We focus on two outcome areas: milk quality and organizational efficiency. In order to safeguard and improve milk quality in expanding markets, efficiency in processing as well as quality assurance systems are needed. Organizational efficiency is also a key factor affecting the sustainability of organizations that operate in a competitive market environment. Organizational efficiency requires a good balance between ensuring rewarding milk prices for members and retaining a part of earnings in the cooperative for use as working capital and for making future investments. The contextual factors on which we focus are e.g. institutions such as regulatory frameworks, economic incentives and policy dialogue facilitation, as we expect these institutions to affect the ability of cooperatives to enhance milk quality and maintain organizational efficiency.

The main research question addressed in this paper is "What is the influence of the external environment on how dairy cooperatives deal with two organizational challenges?" More specifically, how do these cooperatives develop and apply (1) an effective and efficient milk quality assurance system and (2) payment systems that can accommodate the financial needs of both smallholder members and the cooperative organization? 
Challenge 1 - Developing and applying effective and efficient quality assurance systems

The first organizational challenge relates to the development and application of a quality assurance system (Kirezieva et al., 2016). Good-quality milk is important for processors as it enhances the efficiency of processing, but it is also important for consumers as it affects food safety and nutrition security (Luning et al., 2015). In this context, a cooperative faces agency problems between an individual member and the cooperative. The individual member has an interest in reducing effort (and thus costs) in reaching a certain product quality level, while the cooperative has an interest in receiving products of agreed quality level as that directly relates to efficiency in processing and marketing (Ton, 2015). Low-quality milk cannot be used for pasteurized milk. For cheese or yoghurt making, the milk needs to be free of antibiotics. Low and variable milk quality poses a risk for the cooperative in its marketing activities. I mproperly processed milk may result in a food safety risk for consumers, as bacteria from cows may be transmitted to consumers. Also, foreign substances added to the milk may pose a risk to consumers, as was shown by the 2008 melamine scandal (Pei et al., 2011).

Control of milk quality is one of the main issues for which individual dairy farmers may have a different interest than the group - the farmer wants to deliver all milk produced, irrespective of its quality, whereas the cooperative only wants to receive milk that complies with minimum quality standards. This inherent tension between the group (as an organization) and individual members is known as the agency problem. Agency theory addresses information asymmetry and incompatibility of incentives between trading parties. It applies in situations in which one party has an informational advantage over another that can be exploited to the benefit of the advantaged party at the expense of the trading partner, whenever this information asymmetry is costly to correct (Fama and Jensen, 1983).

To solve the agency problem and prevent opportunistic behaviour on the part of members, a cooperative may implement internal rules and regulations to disclose the information of members about the quality of his or her milk through quality testing, and reject the milk or apply discounts in case of sub-standard quality deliveries. However, quality control does not work effectively in situations where quality cannot easily (i.e. against low cost) be measured and in situations where farmers have alternative sales options that do not require good quality milk (Mujawamariya et al., 2013).

\section{Challenge 2 - Offering attractive and cost-efficient payment modalities}

An agricultural cooperative needs to pay for the milk purchased from its suppliers and inputs or services advanced to its members. Many smallholder farmers tend to face cash constraints and need quick payment, whereas the cooperative needs time to complete transactions with the processing client. The cooperative requires working capital in order to resolve this tension - working capital has a price, however. Delayed payment systems are needed when the group cannot access bank loans. However, the cooperative faces competition from other buyers, who may pay farmers directly for the milk produced. Moreover, dairy cooperatives often facilitate inputs (feed), services (veterinary) or loans to members, to be discounted from milk payments. This repayment scheme can become an incentive for farmers to side-sell and thereby obtain a higher price from external buyers. Precise internal rules and regulations concerning milk payment and input provisioning to members will vary according to the needs of the producers, the trust between the cooperative and its members as well as the presence of competing buyers. Payment modalities applied in dairy cooperatives vary according to inter-organizational trust, market dynamics, banking technology, legal provisions and regulations and other types of institutional features.

\subsection{Research methodology}

In each of the two countries, five dairy cooperatives were selected to cover a diversity of organizational forms, which were differently affected by the institutional environment. Each case-study was based on in-depth interviews with each of the three different stakeholder groups: professional staff (e.g. manager and quality manager), board members (e.g. president and vice-president), and members (e.g. a small and a large dairy farmer). The interview reports were coded using Atlas. $\mathrm{ti}^{\mathrm{m}}$ 
software, to facilitate the analysis and synthesis of findings from the cooperatives in each country as well as the comparative analysis between the two countries.

The sample of cooperatives in each country did not pretend to be representative of the sector as a whole, but to be diverse enough in size, location and functions to obtain an insight from different perspectives on the main organizational challenges related to quality assurance, payment system and training of staff. We explicitly aimed at conducting an exploratory study to identify entry points for policies and institutions that may help cooperatives to find effective and efficient solutions for inherent tensions in collective marketing (Ton, 2015). We intended the study to have a wider relevance than only for the two countries included in the study.

\section{Sample of cooperatives in Kenya.}

The Kenya case study covered a total of six dairy cooperatives, all sourcing milk from smallholder producers, but differing in size and activities. Some cooperatives only functioned as bulking nodes for raw milk collected by private processors, whereas other cooperatives had their own processing units. The cooperatives all started with a small number of founding members. As Table 1 shows, some are still small, e.g. the Cheptiret cooperative, whereas others developed into large organizations, such as the Githunguri and Muki cooperatives. Muki Dairy Farmers Cooperative Society collects milk in three catchment districts of Kipipiri, Kinangop and South Kinangop. It owns a modern processing plant, Kinangop Dairy Ltd, which has a processing capacity of 40000 litres daily. Githunguri Dairy Farmers Cooperative Society trades processed milk products under the name 'FRESHA'. I ts average daily milk intake stands at 200000 litres. It has a workforce of 8 000, and turnover was about 6 billion Kenya shillings in 2013.

Average milk production is low, in a range of 2 to 10 litres per day per lactating cow. The Ukuu cooperative has the lowest daily milk volume; it functions as a bulking node, and has no processing activities. Muki and Githunguri, in contrast, are multi-purpose cooperatives with a milk processing unit. All cooperatives source exclusively from their registered members. The main characteristics of these six dairy cooperatives are reported in Table 1.

Table 1 Kenyan dairy cooperatives included in the study

\begin{tabular}{|c|c|c|c|c|c|c|}
\hline \multirow[t]{2}{*}{ Cooperative } & Githunguri & Muki Dairy & Mumberes & Sabatia & Cheptiret & Ukuu Farmers \\
\hline & Cooperative & Cooperative & Cooperative & Cooperative & Farmers & Cooperative \\
\hline Location & Githunguri & $\begin{array}{l}\text { Dunyu Njeru- } \\
\text { Kinangop }\end{array}$ & $\begin{array}{l}\text { Mumberes- } \\
\text { Eldama Ravine }\end{array}$ & Eldama Ravine & $\begin{array}{l}\text { Cheptiret- } \\
\text { Eldoret }\end{array}$ & Kiriane-Meru \\
\hline $\begin{array}{l}\text { Initial number of } \\
\text { members }\end{array}$ & 31 & 9 & 74 & 611 & 20 & 150 \\
\hline $\begin{array}{l}\text { Current number of } \\
\text { members }\end{array}$ & 23000 & 15000 & 3300 & 3400 & 80 & 700 \\
\hline
\end{tabular}

Source: Interviews done by the authors

\section{Sample of cooperatives in Morocco}

Four case studies of dairy cooperatives in Morocco were carried out in 2015/2016, through in-depth semi-structured interviews. The sample included three milk collection cooperatives and one processing cooperative. In addition, two professional organizations related to the dairy chain in Morocco were interviewed. Two of the collection cooperatives are located in large-scale irrigation schemes, the Al Badre cooperative in the Tadla area (eastern-central part of Morocco) and the Al Fouarate cooperative in the vicinity of Kenitra city, in the Gharb large-scale irrigation area (northwestern part of Morocco). The third milk collection co-operative, Al Mouna, is located in the rainfed agricultural area of Khémisset, in the Central-Western part of the country. The fourth cooperative, Colait/Extralait, is a 
dairy processor. It is located in the Gharb irrigation area, and it was established in 1953 during the French colonial era, in order to add value to the milk output of the region and to supply dairy products to growing neighbouring cities. The main characteristics of these four dairy cooperatives are reported in Table 2.

Table 2 Moroccan dairy cooperatives included in the study

\begin{tabular}{|c|c|c|c|c|}
\hline Cooperative & Colait/ Extralait & Al Mouna & Al Badre & Al Fouarate \\
\hline Location & $\begin{array}{l}\text { Gharb irrigation } \\
\text { scheme }\end{array}$ & $\begin{array}{l}\text { Khémisset rainfed } \\
\text { area }\end{array}$ & $\begin{array}{l}\text { Tadla irrigation } \\
\text { scheme }\end{array}$ & $\begin{array}{l}\text { Gharb irrigation } \\
\text { scheme }\end{array}$ \\
\hline Initial number of members & 21 & 12 & 71 & 27 \\
\hline Current number of members & 88 & 9 & 81 & 56 \\
\hline Non-member supply (\%) & 10 & 20 & 0 & 35 \\
\hline
\end{tabular}

Source: Interviews done by the authors 


\section{Organizational and institutional challenges for Kenyan dairy cooperatives}

\section{$2.1 \quad$ Institutional context}

\section{Structure of the dairy value chain}

Kenya has the largest dairy herd in Africa, with smallholders accounting for 70-80 percent of the total production (Wambugu et al., 2011). The sector has an estimated yearly production of 5 billion litres of milk, with most of the production being located in the Rift Valley and Central regions. However, other regions, including Eastern, Nyanza and Western regions, also produce significant quantities of milk. The sector is important for its role in poverty alleviation in both the rural and urban areas. This is reflected in its contribution to food and nutritional security and increased household incomes. The dairy sector accounts for 14 percent of agricultural GDP and 6-8 percent of the country's GDP. Moreover, the sector generates an estimated 1 million jobs at farm level and an additional 500000 in direct waged employment.

Because of fragmentation and production of small quantities, small-scale dairy farmers have realised the need to organize themselves so that they can bulk and sell their milk collectively. Therefore, the marketing of milk in Kenya is dominated by dairy cooperatives. Currently, there are more than 13000 cooperatives, facilitating market access for more than 1.5 million dairy farmers. Cooperative societies and cooperative unions provide milk collection, cooling and bulking services. Processors collect the milk from the bulking units of these cooperatives.

Milk chilling hubs have been promoted in partnerships between cooperative societies and development organizations. These chilling hubs form the interface between farmers and processors. Smallholder dairy farmers transport raw milk either to the local cooling centres or the milk chilling centres/hubs (MCCs). Local cooling centres are normally satellites of the MCCs or are owned by specific processors. Processors collect milk from the cooling centres, MCCs or from roadside collection points.

Of the 5 billion litres of milk produced, 42 percent is consumed at home or sold directly to neighbours (Muriuki, 2011). The remaining 58 percent is sold through either formal or informal marketing channels. The informal market, consisting of 'hawkers' and small shops, accounts for about 32 percent of marketed production, while the formal market handles about 26 percent of milk sold (Figure 2). The formal milk trade is the market segment licensed by the Kenya Dairy Board (KDB). Licenses are issued for milk bars (for up to 1000 litres/day), cottage industries (up to 3000 litres/day), mini-dairies (up to 5000 litres/day), processors (above 5000 litres/day), producers (farmers who process the milk themselves) and distributors (who buy for resale). The processors handle about half of the milk bulked by cooperatives, the other half being sold to informal outlets or directly to consumers. Data from the Kenya Dairy Board indicate that the sector is experiencing a steady growth (Table 3 ).

Table 3 Milk sold through formal marketing channels in Kenya

\begin{tabular}{lccccccccc} 
Year & 2003 & 2004 & 2005 & 2006 & 2007 & 2008 & 2009 & 2010 & 2011 \\
$\begin{array}{l}\text { Quantity sold, } \\
\text { million litres }\end{array}$ & 197 & 274 & 340 & 360 & 423 & 399 & 407 & 516 & 549 \\
\hline
\end{tabular}

Source: Kenyan Dairy Board

In Kenya, milk processing and distribution is undertaken by farmer-owned cooperatives as well as private enterprises. Currently, there are about 54 registered dairy processors, only 34 of which are operational. These processors have a combined dairy processing capacity currently standing at 
2.9 million litres per day. They are, however, operating only at half capacity, their sales accounting for only 12 percent of fresh milk sales in urban centres. Demand for pasteurised milk is low because it is more expensive than raw milk and moreover, many consumers prefer the taste of unprocessed milk (Republic of Kenya, 2013).

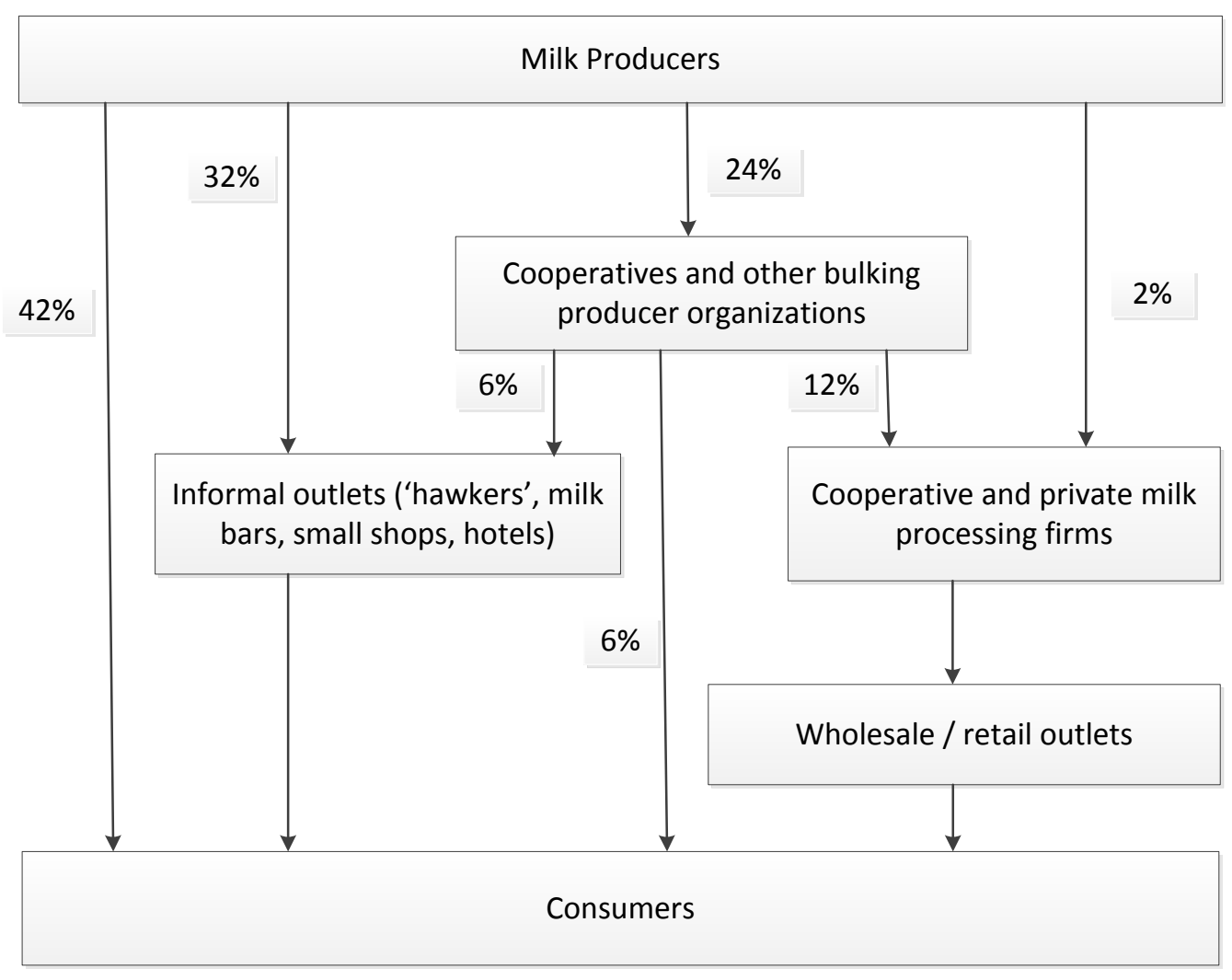

Figure 2 Structure of dairy chain in Kenya, based on Abdulai and Birachi (2009)

The milk processing industry is dominated by five companies, namely: Brookside Dairy Ltd (38 percent), New Kenya Cooperative Creameries (NKCC) (29 percent), Githunguri Dairy Farmers Cooperative Society (Githunguri DFCS) (14 percent), Sameer Agriculture and Livestock Ltd (Daima) (4 percent) and Buzeki Dairy Ltd (4 percent). Other medium-level dairies with a significant intake include Kinangop, Meru Dairy Cooperative Society, and Kabianga Dairy. Smaller specialist dairies include Bio Food Products, Razco Ltd, Raka Cheese, Brown's Cheese and Alpha Dairy.

\section{Policy changes in the dairy sector}

Pricing policy in the Kenyan dairy sector has been undergoing major shifts from the time of independence to date. Omiti and Muma (2000) give three periods of major shifts of pricing policy since 1965.

The dairy sector was guided by a milk quota system up to 1971. The government intervened directly in the market and with subsidized services (Muriuki, 2011). In this phase, dairy processing and marketing was undertaken by independent factories. The next phase in dairy policy was between 1971 and 1992 and was based on pan-territorial liberalised production. However, also in this period the government played an important steering role, with a uniform pricing system. Dairy processing developed simultaneously with production through the Kenya Co-operative Creameries (KCC). Until 1992, KCC was a monopoly with a countrywide network of 11 processing plants and 11 cooling centres with 26 sales depots (Omiti and Muma, 2000). In 1992, the dairy industry was liberalised, leading to decontrol of producer and consumer prices (Omiti and Muma, 2000).

The institutional framework for the dairy sector includes the Ministry of Agriculture, Fisheries and Livestock Development; the Kenya Dairy Board (KDB); the Livestock Development Services 
responsible for extension and regulatory services; the Kenya Agricultural Research Institute (KARI); and the Kenya Animal Genetics Resources Centre (KAGRC). There is an elaborate legal framework within which the sector is regulated. Whereas the policy framework for the dairy industry is the responsibility of the national government, the development of the sector, including veterinary and extension services, has been devolved to the county governments (Makoni et al., 2014). This transition to a devolved governance system has created opportunities and challenges for the development of the sector in terms of increasing productivity and competitiveness.

\section{Value chain coordination mechanisms}

The current regulation governing the dairy sector is the Dairy Industry Act, Chapter 336 of the Laws of Kenya. This act allowed the establishment of the Kenya Dairy Board (KDB) in 1958. The main objectives of the board are to organize, regulate, and develop efficient production, marketing, distribution and supply of dairy products. The KDB is governed by a board of directors made up of stakeholders drawn from farmers' associations (e.g. umbrella organizations of dairy cooperative societies representing different regions), the government (the Ministry of Agriculture, Livestock and Fisheries) and the private sector, such as processors (e.g. the Kenya Dairy Processors Association) and banks. The KDB has branches in Bungoma, Embu, Keticho, Meru, Nairobi, Nakuru, Nyeri, Voi, Eldoret, Kakamega, Kisumu, Mombasa, Naivasha, Narok and Thika. The regional branches offer licenses to dairy operators. In addition to a fixed licence fee, KDB charges KSh 0.4 per litre of milk sold by the operator.

All first-tier primary dairy cooperatives are members of a second-tier regional union of cooperatives within their economic region. The unions provide services to member cooperatives, such as enhancing links with private processors, assisting the cooperatives in meeting KDB standards of operations and linking individual members to input dealers through a credit input supply system as well as to the banking sector, usually the Cooperative Bank.

\subsection{Organizational challenges and solutions}

Most of the milk for processing plants is sourced by primary cooperatives that collect it from smallholder farmers. Primary cooperatives are the main link in the dairy value chain, through which quality requirements of processors are communicated to farmers and where quality control takes place. In the absence of a nearby consumer market for raw milk, the cooperative is the main market outlet for smallholders' milk. In some regions, several cooperatives procure from the same geographical area, leading to competition in service delivery and off-farm prices. When a consumer market is nearby, informal buyers procure milk from farmers to deliver directly to small scale informal processors or directly to consumers. These informal traders, or 'hawkers', compete directly with the cooperatives in terms of prices (paying higher prices), payment modalities (paying directly in cash) and quality requirements (lower). Dairy processors source mainly in more remote areas, where prices of raw milk are lower (Foreman and de Leeuw, 2012). Interviews with the cooperatives indicated several ways to cope with this competition while remaining attractive for farmers and reliable for processing plants. A summary of the challenges faced by the dairy cooperatives in Kenya and the measures adopted to overcome them is reported in Table 4. 
Table 4 Main organizational challenges in Kenyan dairy cooperatives

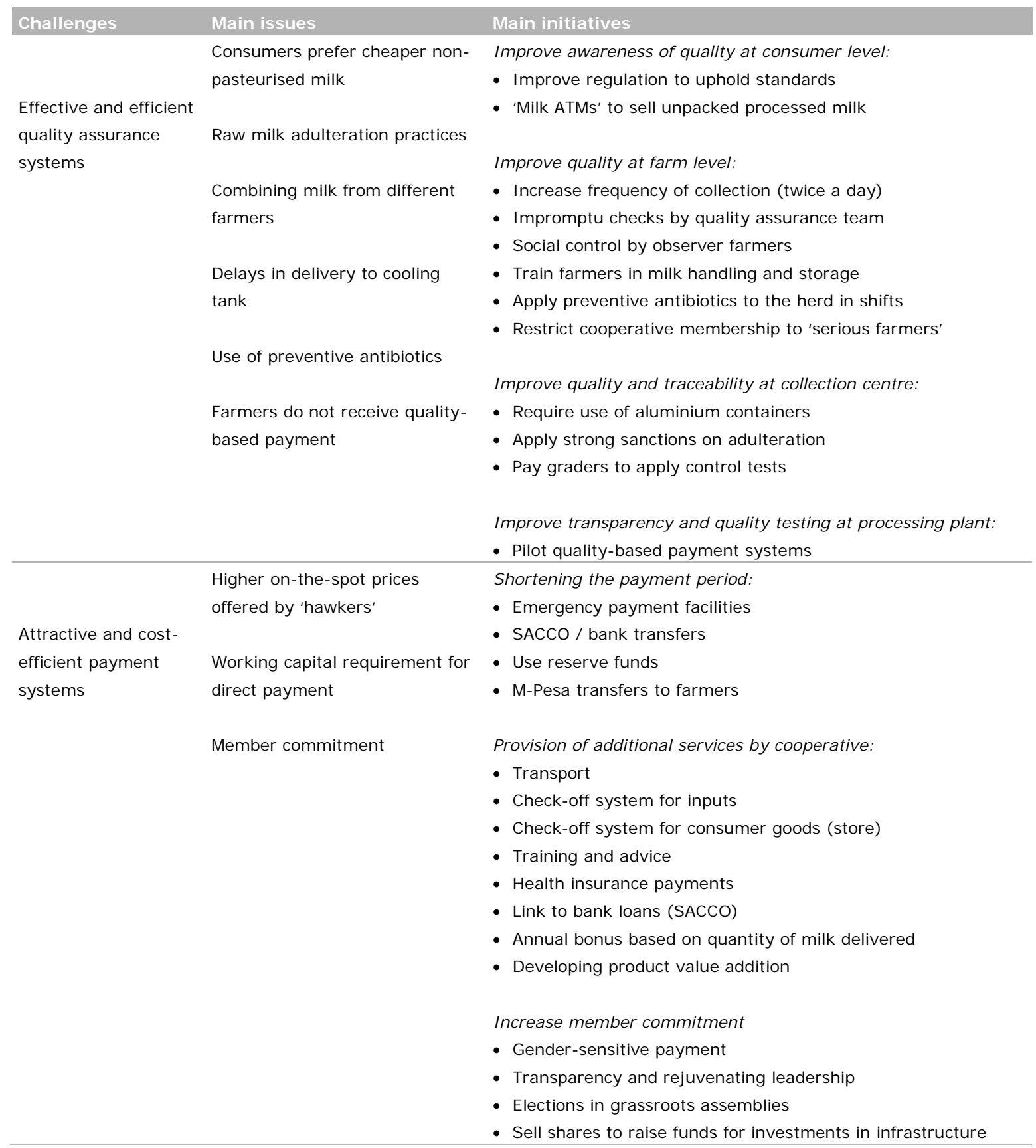

\section{Challenge 1 - Developing effective and efficient quality assurance systems}

When milk is taken fresh from a cow's udder, it has very low bacterial counts. As a result of naturallyoccurring anti-bacterial substances in fresh milk, the bacterial counts remain low for 3 to 4 hours ('lag phase'). Thereafter, however, the bacterial content starts to increase logarithmically ('log phase'), doubling every half hour. When fresh milk is mixed with 'log phase' milk, e.g. when morning and evening milk are mixed in the same milk container on the farm, or if the container or cooling tanks are not cleaned properly at the collection centre, all milk in these containers will come into log phase immediately. The Kenya Dairy Board indicates that milk quality has improved, but was originally at a very low level. Foreman and De Vries (2012) refer to a study in 2005 showing that the milk in five sampled collection centres had a bacterial count that was four to five times the upper limit for Grade III milk. Other research in 2008 showed that even after being pasteurised, several processed products had coliform contamination, indicating poor post-processing hygiene.

Initiatives to improve awareness of quality at consumer level The public is not well informed about the dangers posed by poor food safety practices, and the control of food processors is limited, with a large informal sector having no effective food safety monitoring 
systems. To prevent health problems, most consumers boil the milk before consumption (Muriuki, 2011). In 2007, the Kenya Bureau of Standards introduced high quality thresholds for milk, similar to those used in developed countries, but in practice no milk complies with these norms and there are no effective regulations nor sanctions (Ndungu et al., 2016). The standards are set so high to counteract eventual market access limitations for dairy exports (Foreman and de Leeuw, 2012).

“... at the moment in Kenya much of the milk being processed does not comply with the standard and therefore in theory the processors could be prosecuted for use of nonconforming milk. Grade III milk, given an upper limit of $2.0 \times 10^{6} / \mathrm{ml}$, makes the use for processing of milk with higher bacterial counts non-conforming, and therefore technically illegal. Elsewhere, standards have sometimes required that high-count milk be used for industrial processing and been prohibited for use in the manufacture of fresh dairy products. The Kenya/EAC standard does not distinguish between permitted uses for each of the grades." (Foreman and de Leeuw, 2012).

One way to increase the sale of processed milk in urban markets is to reduce packaging costs, as the lower consumer price is a decisive factor for the high demand for unprocessed milk. Some processors have installed milk dispensers ( known as milk ATMs). These dispensers are commonly found in supermarkets and milk bars. Most of the dispensers are placed by the company Kinangop Dairies Ltd. Some cooperatives, such as Mumberes and Miku Farmers' Cooperative, have also by-passed the large processing companies, and enter the local market with milk ATMs selling raw milk per litre.

Initiatives to improve quality at farm level

Most cooperatives indicate that they do not face many quality challenges and that the cases of milk rejection are few. However, cooperatives and processors do occasionally reject milk from farmers due to acidity, adulteration and mastitis.

"Sometimes, milk spoils fast due to high temperatures in the area. Sometimes farmers mix morning and evening milk and this leads to spoilage. Another challenge is that some farmers produce small quantities of milk and cannot fill the 50 -litre capacity cans. So during collection, milk from an area is combined into one can. In case some milk from one farmer is adulterated the whole can is adulterated and leads to rejection of all milk on only one farmer's account." (Interview with Mumberes)

Several cooperatives have started to increase the frequency of raw milk collection. For example, Mumberes has started collecting the afternoon milk from farmers that have a substantial production. Other cooperatives, including Githunguri, even oblige farmers to deliver milk twice a day. If they fail to do so they are fined $20000 \mathrm{KSh}$. This severe sanction has been introduced as a complement to another control system used by cooperatives: impromptu visits of inspectors or a quality assurance team. Githunguri sanctions farmers when water is added, but directly expels members who add soda ash.

"The reason for this is that since the society conducts random inspections and very often it is then assumed that if a farmer fails to deliver his or her milk it means that he/she is trying to avoid being caught by the inspectors. And therefore he is treated the same way as that farmer who was caught having adulterated the milk and penalised." (Interview with extension officer of Githunguri).

I mpromptu visits by paid staff are cost-efficient in larger cooperatives. Smaller cooperatives have introduced systems of social control by peer farmers to prevent adulteration, and other cooperatives are still looking for effective means of doing so.

"Currently, any farmer found with adulterated milk is simply told to take back the milk without other penalties. However, the cooperative is working on the penalties and fines to be charged in case of repeated offences. This is the result of rising number of cases of milk adulteration. This gave the cooperative a bad reputation and farmers experienced huge losses following milk rejection." (Interview Sabatia) 
In addition to adulteration, the presence of antibiotics in the raw milk poses serious quality problems for the processor (for processing milk into yoghurt and cheese) and consumers (allergy). The use of antibiotics as a preventive medicine is widespread. Several cooperatives organize training to limit

use of antibiotics and to apply cattle handling methods that reduce the incidence of mastitis and other infectious diseases. For example, Ukuu cooperative emphasises the use of separate towels for drying the udder of each cow. One cooperative, Cheptiret, instructs its members to apply preventive antibiotics only to parts of their herd, and, for some days, only deliver milk from untreated ones. The use of antibiotics in shifts guarantees that the farmer has some income and that the amount of milk spoilt or used for home consumption is manageable. Cheptiret also restricts its membership to 'serious farmers' having more intensive dairy production, to ensure that they safeguard the milk quality.

I nitiatives to improve quality at the collection centre Milk adulteration is detected mainly at the cooling centre, using lactometers. Most cooperatives have graders to perform this task. Generally a first check is done by the driver who collects the milk (mainly by smell) and when the milk enters the cooling centre ( $\mathrm{pH}$-test density test). This quality control is accompanied by a severe sanction procedure, such as the one followed by Cheptiret cooperative.

"In case it is a worker who had delivered the rejected milk, the worker is given a letter to take to the farmer explaining the reasons for the rejection of the milk. The farmer is given a warning. In case the milk is rejected three times, the cooperative sends the extension officer to the farm to discuss the problem and try to assist the farmer after which repeating the same mistake leads to the expulsion from the cooperative. All members adhere to these rules." (Interview Cheptiret)

According to Foreman and de Leeuw (2012) and Ndungu et al. (2016), the quality of the milk analysers as currently used in these cooling centres are not suitable for an uncontested quality-based payment system, because of the poor stability of calibration and the accuracy and replicability of the results obtained. The main interested party in effective quality control is of course the processor. In many primary cooperatives, therefore, the staff responsible for the control is paid directly by the processing company or the cooperative union.

I nitiatives to improve transparency and quality testing at processing plants The Kenya Dairy Board, together with SNV, Land O'Lakes International Development and the Gates Foundation, have introduced pilots of quality-based payment systems. The results are still meagre, however. A credible quality-based payment system needs a system of control-on-control. Foreman and de Leeuw (2012) indicate that processors are not inclined to facilitate external inspections in their plant or third-party laboratory checks on their quality control. Quality-based payment by processors is also limited to the deliveries from the cooling centre and cannot be transferred directly to individual farmers, in the absence of a credible quality control system at the level of the collection centre.

In theory, quality-based payment systems may boost quality. Bonuses for high-grade milk can be financed from penalties for low-grade milk. Investment in quality control and extension services can be paid back from the added value created in processing higher milk quality. However, a context of fierce competition with an informal sector that will not apply these quality requirements, combined with the higher prices that these informal 'hawkers' pay for the raw milk, make it highly unlikely that individual farmers can be reached by these quality-based incentives.

\section{Challenge 2 - Offering attractive and cost-efficient payment systems}

Cooperatives compete both with informal buyers ('hawkers') and among themselves. In some areas there are several cooperatives, which often, for one reason or other, have split from the same initial cooperative (e.g. the case of Ukuu Farmers Dairy Cooperative). Therefore, the loyalty of the member to his or her cooperative is always contested and the transactions between the member and the cooperative are continuously negotiated. The main issue referred to by farmers in the interviews was related to pricing, whereas delayed payment was less important. Payment modalities, however, proved a key factor in enabling the cooperatives to reduce their costs. Modern banking systems to pay 
for the milk have opened up additional services for members, especially in accessing loans from the banks to which the dairy cooperatives make monthly payments.

Initiatives to shorten the payment period

In all cooperatives, there is a facility for farmers to be paid before the agreed monthly

payment day, with a credit ceiling based on the value of the milk delivered on that day; the credit is then cancelled with the next monthly payment. Longer-term loans are possible from several of the cooperatives, e.g. in Muki, Mumbers, Sabatia, Githunguri, because they manage, or work in close collaboration with a Savings and Credit Cooperative (SACCO). In contrast, Cheptiret works with any bank at which a farmer has an account.

"When members borrow, this is a personal initiative and arrangement between the farmer and his/her respective bank, without the cooperative" (Interview Cheptiret)

All cooperatives have monthly payment systems. While members are usually paid with a month delay, Sabatia needs only two days and Cheptiret even pays the farmer before the processors have made the transfer, using their reserves as working capital. In practice, farmers are satisfied with these monthly payment.

I nitially, farmers were paid in cash but the mode of payment is changing, with the majority of farmers now being paid through the bank. However, some of the older farmers still insist on being paid in cash, because they find it difficult to follow bank procedures and also wish to minimize transaction costs. However, paying cash poses a security risk to cooperatives (Interview Ukuu). Muki Farmers' Cooperative introduced a sophisticated payment system based on mobile phone credits: the money is deposited in the farmer's account in Muki SACCO, and transferred to his or her M-Pesa (mobile phone payment system) account. The farmer can then withdraw the money from any M-Pesa outlet, save it in an M-Shwari saving account, transfer it to another bank account or make purchases with it using the Lipa $\mathrm{Na} \mathrm{M}$-pesa in shops.

I nitiatives to provide additional services

The usual way for cooperatives to compensate for lower prices or delayed payments compared with 'hawkers' is to offer additional services. All cooperatives offer their members transport service for the milk. Generally, this transport service is offered at no cost, except in the case of Sabatia that offers higher prices (around 10 percent) to farmers that supply directly to the collection centre. Most cooperatives are multiple-service cooperatives. For example, Muki Dairy Farmers' Cooperative provides an impressive list of services to its members, including training, health insurance, livestock insurance, input supply, cash advances, artificial insemination services and end-of-year bonuses.

All cooperatives also use a check-off system for inputs (animal feed, medicine) procured from a designated agrovet-shop, generally an economic unit in the cooperative. Especially the larger cooperatives can obtain reductions on the prices of these inputs due to economies of scale and negotiation power. Membership of the cooperative therefore translates into lower input costs compared to non-members.

Githunguri also allows food items bought in the cooperative food store in its check-off system. According to a member "this has reduced the incidences of men use all the proceeds from milk leaving the family without food."

Initiatives to increase member commitment

The Cheptiret cooperative has an innovative feature in their payment system. To ensure that the whole family participates in milk production activities and to ensure empowerment of women, the cooperative has a policy that morning milk is recorded in the name of the husband and milk delivered in the evening is added to the wife's account.

“This policy is to ensure women's empowerment and to reward women who mostly participate in dairy activities and it ensures women's inclusion in the dairy operations." (Interview Cheptiret) 
To boost member commitment to the rules and regulations within the cooperative, some cooperatives mention a need to increase transparency and involve younger farmers in daily management. Mumberes Cooperative increased member commitment in the General Assemblies by organizing decentralised election in the villages in which the farmers live.

“... elections are conducted at the grassroots level and not during Annual General Meetings at the headquarters as most cooperatives do. This ensures transparency and near 100 percent participation of members. The main reason that informed this change was the fact that very few people participated in elections because they had to travel long distances. This led to low voter turnout. To make it easier therefore, the voting was taken closer to them at the grassroots." (Interview Mumberes)

Several cooperatives, for example Sabatia, offer special shares to members to pay for new infrastructural investment in the cooperative, such as storage facilities. When possible, farmers are paid a dividend based on the profit made with the particular investment. Most cooperatives pay a bonus for each litre of supplied milk. The bonus is around 5 percent of the price of milk in the case of Sabatia and 3 percent in the case of Ukuu Farmers' Cooperative.

\subsection{Implications for the institutional environment}

\section{Coordination in the dairy chain}

The dairy market in Kenya is highly informal, but the formal sector is well-organized, with a key role for the Kenyan Dairy Board and a relatively well-structured cooperative movement. Coordination in the dairy chain in Kenya is defined by the type of contracts used in transactions between the producers and buyers of milk (Birachi, 2006). Three main coordination mechanisms that were identified are spot market, verbal contracts, and written contracts. The informal market mostly relies on spot market and producers get cash immediately to offset their expenses and meet their needs. Prices paid in the informal market are also slightly higher than those paid by cooperatives.

A disadvantage for farmers selling in the informal market is that they do not benefit from quality feeds and other services provided by the cooperative. Some cooperatives, for instance Muki Farmers' Cooperative, have loose contracts with producers, whereby producers supply milk to the cooperative but can sell to other cooperatives if they so wish. In the Githunguri Dairy Cooperative, however, member producers are not allowed to sell to other cooperatives. The producers supplying milk to cooperatives have the advantage of receiving a lump-sum payment at the end of the month as well as benefiting from other services such as loans, training, extension services as well as inputs at subsidized rates.

Some of the cooperatives, including Muki Dairy Farmers Cooperative and Githunguri Dairy Farmers Cooperative, organize the processing and marketing themselves - a strategy of vertical integration. These cooperatives bulk the milk from producers, process it into various dairy products and sell these products under their own brand names. They set prices and quality standards as well as minimum delivery quantities. The cooperatives undertake the function of input suppliers as well. The ability of milk producers to join together to form a cooperative is a form of horizontal coordination. This enables the producers to benefit in terms of collective action, reducing their transaction costs.

Moreover, in Kenya there is the emergence of horizontal coordination between dairy marketing groups, as seen in the case of Baringo Agricultural Marketing Services Cooperative Services (BAMSCOS), Meru Central Dairy Cooperative Union and North Rift Cooperative Organization. These regional unions bring together primary cooperatives and provide services to members. Examples of such services include enhancing links with private processors, assisting the cooperatives in meeting the KDB standards of operations and linking individual members to input dealers or stockists through a credit input supply system as well as through the banking sector, usually the Cooperative Bank. 


\section{Financial instruments and capacity development programmes}

The goal of ensuring that quality milk is supplied to the cooperatives has not been fully realized in Kenya. Milk delivered to processors is often adulterated with water and other additives and does not meet the microbial standards set by the Kenya Dairy Board and the Kenya Bureau of Standards. This is due to the fact that most farmers cannot afford the necessary transport equipment or the milk testing equipment. However, several programmes are under way to achieve this. Under Feed the Future programme, USAID trains bank employees on best practices for "value chain lending," or providing financial services to farmers, suppliers, processors, and buyers all across a given sector to reduce the costs and risks of doing business. The most successful partnership resulting from this effort has been with Kenya Commercial Bank (KCB), the largest Kenyan bank in assets. Sixty-four KCB employees have been trained in value chain lending and approximately US\$ 9 million in loans have been issued in the dairy sector since J anuary 2012 across the 32 KCB branches. The partnership is supporting the roll-out of two new financial products: a dairy herd loan and an asset finance loan.

Another programme is the Kenya Market-led Dairy Programme (KDMP), funded by the Netherlands Embassy in Kenya and carried out by SNV. This intervention aims to facilitate processors to pilot quality-based milk payment systems (QBMP), by providing technical advice and other support. This is done in collaboration with the Kenya Dairy Board. The proposed system aims to utilize the existing milk testing facilities at collection centres and at processing plants, with the provision of additional testing equipment. Bulking centres have been the main focal point for this work, with various NGO project investments in the rehabilitation and provision of milk cooling tanks, purchase of hygienic dairy equipment, provision of business management training, and other improvements needed to make formal-sector marketing and business development more effective and attractive.

Moreover, in 2008, the Gates Foundation launched the East Africa Dairy Development (EADD) Project. The EADD strategy follows the "milk hub" approach, which uses milk-bulking centres as the focal points around which business development linkages are created between farmers, buyers and inputs suppliers, thereby creating a web of market links. The milk hub development strategy focuses attention on bulking centres as a business enterprise and provider of services needed to support dairy production. The objective is to promote stable market systems that are attractive to farmers because of the services offered. This, in turn, allows the hub to create marketing relationships with dairy processors as purchasers of the milk, and so open the way to accessing other benefits including the ability to mobilize private finance for investments in cooling tanks and other infrastructure needed for the growth and development of the cooperatives.

Currently, the Ministry of Agriculture, Livestock and Fisheries is planning to provide 1000 cooling machines as part of an effort to enhance the sale of quality milk. These milk cooling machines are part of a KSh 10 billion grant package from the Dutch Government to mechanise Kenya's dairy sector and will be supplied to dairy cooperative societies. Additionally, the Kenya Dairy Board will train milk "hawkers" and issue them practicing licences. The licensing is aimed at promoting good handling of milk, in order to curb diseases resulting from the consumption of bad milk. The Ministry is focusing on ensuring that hawked milk is processed, in order to make it safer and make the informal milk trade acceptable. For example, as of August 2016, informal traders will be able to purchase pasteurised milk from a centralised point and then sell it to other market segments.

\section{I nstitutional support for effective smallholder collective action}

The ability of dairy cooperatives to offer better services to their members depends on the broader policy and institutional environment. The main role of the Government of Kenya is to create a conducive environment for private sector investment in milk production, processing, marketing and delivery of key support services. This function is carried out by KDB in collaboration with the Ministry of Agriculture, Livestock and Fisheries, the mandate being to improve the producer price of milk, lower the consumer price and increase milk intake by processors (Tuei, 2010)).

Since 2003, the Government of Kenya has put in place several measures to revive the dairy industry, such as restructuring and capacity building of the Kenya Dairy Board; revival and strengthening of the New KCC and the Agricultural Finance Cooperation (AFC); review of dairy policies and regulations; and encouragement of development partners and the private sector to provide more resources to the 
industry. This has translated into increased public and donor investment in the dairy sector, and cooperatives have been strengthened in their capacities to collectively bulk and sell milk and access extension services.

The dairy sector is able to influence Kenyan public policy by analysing and proposing regulations that constrain growth and quality upgrading. For example, the Kenyan Market-led Dairy Programme, supported by SNV and Embassy of The Netherlands, engages with policy and opinion makers to identify or address issues such as fiscal policies regarding tax exemptions for dairy equipment and liquid processed milk, regulation of the raw milk market, the introduction of standards for the dairy industry, the development of standards for milk fortification, piloting of new energy- and protein- rich fodder seeds, the regulations regarding the import of heifers, and the institutional environment for practical dairy training. 


\section{Organizational and institutional challenges for Moroccan dairy cooperatives}

\subsection{Institutional context}

\section{Structure of the dairy value chain}

The dairy chain in Morocco is one of the main animal production chains of the country. It is particularly important from a socio-economic, employment, as well as a nutritional point of view, given the range of dairy products destined for consumption (Sraïri, 2011). The dairy sector in Morocco generates close to US\$800 million annually. More than 300000 full-time producers and approximately 100000 seasonal producers earn their living from dairy farming. The dairy chain in Morocco is characterized by a duality. On the one hand, there are strong players mainly represented by private processing groups and large multinationals such as Centrale Danone, whose capital is almost totally controlled by the global player Danone ( 96 percent of its capital); on the other hand, cooperatives such as Safilait and Les Domaines Agricoles are progressing rapidly, as is COPAG

(Coopérative Agricole d'Agrumes), a large cooperative group in southern Morocco (Figure 3). Centrale Danone is currently the leading dairy agro-business firm in Morocco as it processes up to 30 percent of the total raw milk volumes produced annually throughout the country.

Approximately 65 percent of milk production in Morocco goes through the formal sector, whereas 13 percent goes through informal channels. The remaining 22 percent is used on-farm for selfconsumption (Sraïri et al., 2013) \}. Milk deliveries to dairy collection cooperatives, which are further processed by the industrial societies, are crucial for the supply of milk to large urban centres, as imports are quite limited (less than 15 percent of the total amount of milk consumed in the country is imported).

The dairy sector depends heavily on rainfall, which has a direct impact on fodder production. There are agro-ecological challenges due to limited water supplies, as the annual water availability per capita stands at about $750 \mathrm{~m}^{3}$. Water shortages and the impacts of climate change may affect animal products such as milk and meat, both of which have important water requirements (Hoekstra, 2012). Therefore, 65 percent of milk production is concentrated in regions having large-scale irrigation schemes. This issue constitutes a real challenge for the future of intensive dairying in Morocco, given the increasing demand of water by the agricultural sector and the competition between agricultural commodities for this resource. Recent research shows that the water footprint for a single kg of milk under irrigated conditions in Morocco is almost 1.6 cubic meters (Sraïri et al., 2016). 


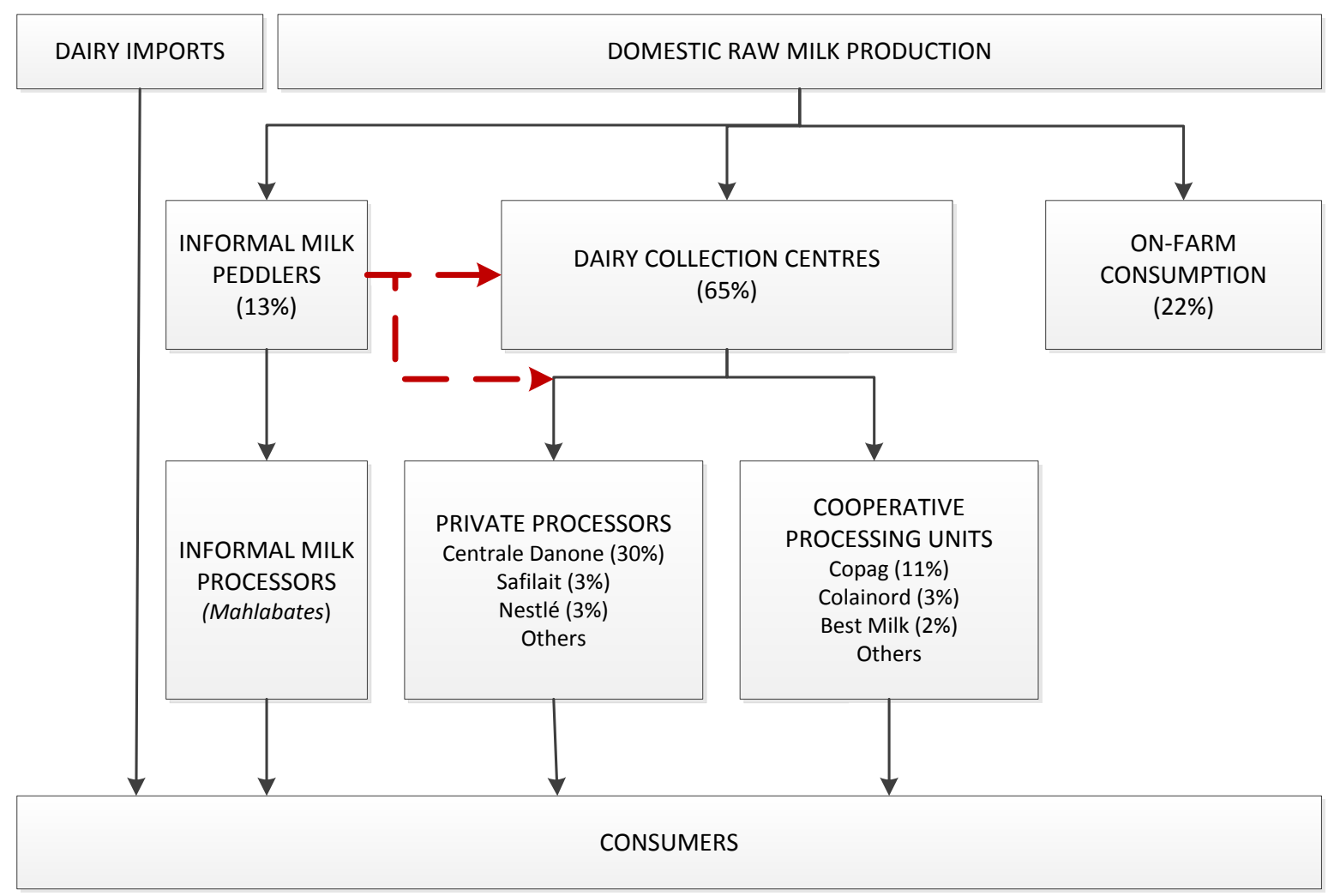

Figure 3 Structure of the dairy chain in Morocco (based on: Sraïri et al., 2013)

\section{Policy changes in the dairy sector}

The current structure of the Moroccan dairy industry is the result of an historical process consisting of roughly five phases: :

1. At Independence in 1956, the sector was entirely driven by the government, as investments rarely involved foreigners. The dairy value chain was disorganized and dairy farmers were dispersed. Distribution ranges were short, as the dairy industry was still embryonic and cities were mainly supplied directly from neighbouring farms.

2. The 1970s marked a turning point, with the adoption of a national dairy policy, focusing on the most favourable areas of the country in which large-scale irrigation schemes were developed. The Ministry of Agriculture then launched a strategy called the 'Dairy plan', mainly aimed at strengthening the Moroccan dairy value chain from production to processing and consumption. This strategy was backed with a series of positive incentive measures such as heavy taxes on imported milk powder and support to farmgate milk prices, which then represented 75 percent of the consumer price. This policy led to a duality between production and consumption areas. The former are located near the mountain areas (and dams) of the central and eastern parts of the country, whereas the latter are mainly near large urban centres along the Atlantic coast. This geographical separation results in relatively high transportation and processing costs of milk before it can be distributed for consumption.

3. The third phase, in the 1980s, was marked by Structural Adjustment Programmes, which came into force in 1983. These hailed a liberalization of the economy, which led to the withdrawal of public policies and resulted in significant budget cuts affecting various existing agricultural incentives. Prices of most feed concentrates in livestock farms soared. By the mid-1980s, Stateowned dairy cattle farms had been dismantled. On the positive side, smallholders adopted the idea of diversifying their sources of income by rearing cattle of imported origin with higher milk yields. The progressive disengagement of the State from the dairy sector during these years resulted in the emergence of private operators, including the farmers themselves, advocating for the sector with a collective voice. In this period, public authorities encouraged the creation of professional associations. In 1988, the National Cattle Breeders' Association (Association Nationale d'Eleveurs Bovins- ANEB) was established, bringing together representatives from various regions throughout 
the country. ANEB took over some of the previously publically provided extension services, such as artificial insemination, record keeping, etc.

4. In 1992, the total liberalization of milk prices throughout the value chain marked the fourth phase of the evolution of the dairy sector. This induced a process in which farmgate milk prices stagnated while consumer milk prices steadily increased (Table 5). This created room for the emergence of informal milk collection circuits to supply neighbouring large cities, particularly in the northwestern part of the country along the Atlantic coast (cities such as Casablanca, Rabat and Kenitra). The raw milk was sold in small shops known locally as Mahlabates. Overall, the sector has kept on growing steadily to meet increasing domestic demand.

Table $5 \quad$ Milk prices in Morocco, 1995-2015

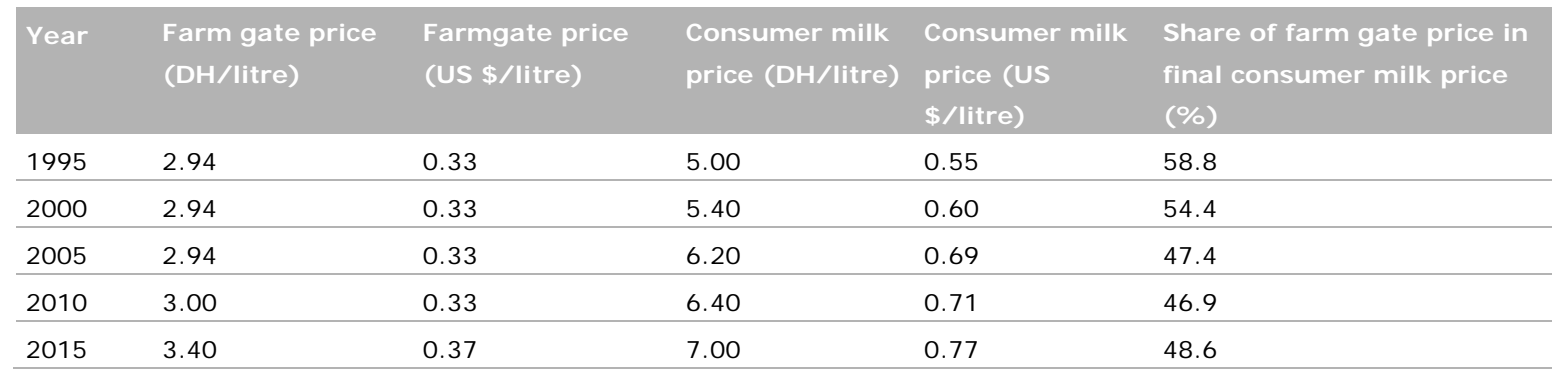

Source: Sraïri (2015)

5. The fifth phase started in 2008, when the government intended to re-articulate the dairy chain. Since then, dairy production has been supported by the Green Morocco Plan. Moroccan authorities have reiterated their commitment to the agricultural sector and to producers. The recombination of imported milk powder is marginal because of high duties on imported milk powder and dairy derivatives. I mports may occur in periods of drought and also to cover an occasional increase in demand, such as during the holy month of Ramadan. In 2013, the government increased farmgate prices by 5 percent (from US\$ 0.33 to US\$0.35 per litre) following a 9 percent increase in the price of milk by the leading dairy company, Centrale Danone. In May 2014, this company also imposed a 10 percent consumer price increase for yogurt and cottage cheese.

\section{Value chain coordination}

The establishment of the Green Morocco Plan in 2008 prompted the need for each commodity chain to create its own governing body to represent operators in the sector. As a result, FIMALAIT, the Moroccan Inter-professional Dairy Federation, was created in 2009. This inter-professional body brings together members of cattle breeders' associations, milk collectors and dairy processors.

FIMALAIT is the only legitimate body to represent the dairy chain. It is eligible for receiving public funds for programmes dedicated to the development of the dairy chain. The first meeting of FIMALAIT also included representatives from the Ministry of Agriculture. During its formation, the organization exposed a number of trust-related issues among actors, which were due to a lack of clear governance mechanisms. For example according to ANEB, some dairy processors had not accepted the idea of discussing sensitive issues regarding the dairy chain. In addition, Centrale Danone insisted on having its own group of dairy farmer suppliers (namely the Féderation Nationale des Producteurs Laitiers FNPL) to be represented within FIMALAIT instead of ANEB being the only representative of cattle breeders at the national level. Thereafter, with the intervention of State authorities, ANEB and FNPL merged to form FENEPROL (Fédération Nationale des Eleveurs Producteurs Laitiers), which then became the only representative body of dairy farmers at the national level. On the dairy processing side, private companies as well as dairy processing cooperatives formed the Fédération Nationale des Industriels Laitiers (FNIL) and this entity is also represented within FIMALAIT. Ultimately, FENEPROL and FNIL joined to form FIMALAIT. 


\subsection{Organizational challenges and solutions}

This research focuses on two outcome areas: milk quality and organizational efficiency. A summary of the challenges faced by the dairy cooperatives in Morocco and the measures adopted to overcome them is reported in Table 6.

\section{Challenge 1 - Developing and applying effective and efficient quality assurance systems}

The quality of raw milk is low in Morocco, mainly because of poor hygiene (i.e. the level of contamination by microorganisms in the milk). Another critical issue related to milk in Morocco is residues of antibiotics, which results both in important quantities of unsold milk and also food safety issues.

Table 6 Main organizational challenges in Moroccan dairy cooperatives

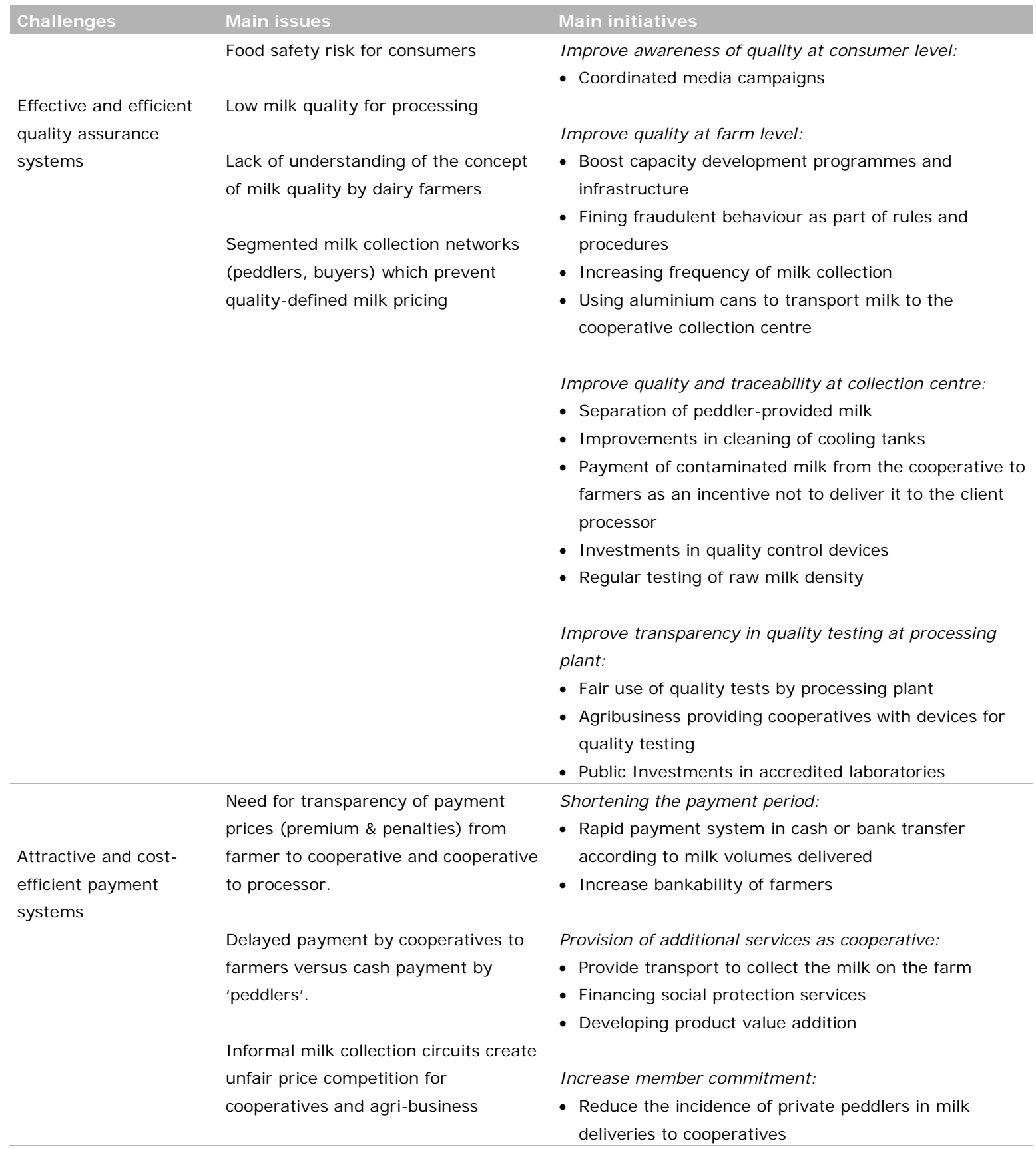

All stakeholders in the dairy chain acknowledge that on-farm investments and better handling practices are needed to improve milk quality. Nevertheless, the price incentives for quality that are paid by the processors are not translated into quality-differentiated prices at farm-level. Payments to 
farmers are based on volumes delivered rather than on the quality of milk. This implies that farmers lack incentives and reward mechanisms to produce quality milk (Sraïri et al., 2009). This lack of price incentive for milk quality is difficult to address, given that the offer of raw milk from smallholder farmers is fragmented. Small volumes of milk are delivered daily by smallholders to 2250 small collection cooperatives throughout the country, before supplying the processing units. Dairy farmers can switch easily between buyers, and are free to sell to informal peddlers or other cooperatives that collect milk in the area if these pay a better price or apply lower quality standards. Especially in the dairy basins located close to the large cities, there are multiple private peddlers who collect milk from the farms and deliver it to the cooperatives. These peddlers mix the milk collected from several farms, making it difficult to avoid contamination or implement efficient tracing systems.

In general, farmers are perceived as not being sufficiently aware of the consequences of antibiotic residues in raw milk for further processing. According to interviews by the Al Badre cooperative, for most farmers the notion of milk quality remains insufficiently understood due to the numerous parameters it consists of (hygienic, chemical and physical). They feel that there is a lack of clarity on the criteria used to measure milk quality. Moreover, the premium paid by the processing client to the cooperative for improved milk quality does not reach individual farmers despite their efforts to comply with these requirements, for instance by using aluminium cans.

Initiatives to improve awareness of quality at consumer level Coordinated efforts of the stakeholders in the dairy value chain, organized in FIMALAIT invest in publicity and media coverage to increase processed dairy consumption. The dairy sector has recently suffered from bad publicity related to the quality of dairy products and the assumption of a negative effect of dairy consumption on human health, such as increased risks of cancer.

Unfortunately, this issue was exacerbated in 2015, just at a time when there was an overproduction because of climate conditions. With a view to rebuilding the reputation of the sector and solving the issue of reduced dairy product sales, the interprofessional organization FIMALAIT launched a large campaign that included scientific conferences and television advertisements, aimed at promoting the consumption of dairy products.

I nitiatives to improve quality at farm level The Al Mouna collection cooperative has increased the frequency of milk recollection. However, these measures alone are not considered sufficient to guarantee the required milk quality. Therefore, the Al Fouarate cooperative has moreover requested its members to use only aluminium cans to transport the milk from the farm to the collection centre, in order to meet the requirements of its client (i.e. Centrale Danone) with regard to milk quality. However, this measure did not reach a consensus among all farmers because of the high cost and heavy weight of the cans.

I nitiatives to improve quality and traceability at the collection centre

As one of the more obvious organizational solutions, the Al Fouarate cooperative started to separate the milk delivered by peddlers from the batches coming from private farms. This improves traceability and facilitates coordination with members on quality issues.

In order to deliver quality milk, many of the cooperatives studied improved washing of the milk tanks with specially developed disinfection methods. Al Badre cooperative, for instance, bought a high-pressure cleaner to clean the tank. The Al Mouna cooperative uses a product called "Easy Foam VF 32" provided by its client, the dairy plant Safilait.

Al Mouna cooperative has established a system of mandatory milk collection twice a day with frequent measurements of raw milk density and a daily testing of antibiotic residues. This system enables the cooperative to meet the dairy plant's quality requirements. But even when the collection cooperative puts in place these more sophisticated systems of testing for antibiotic residues, acidity and density, as in the case of Al Mouna and Al Fouarate, the testing is not conducted systematically, because of cost issues. In practice, the tests were only applied on samples from those farms at which cooperative managers suspected fraudulent behaviour. 
As a rare exception, one of the cooperatives preferred to remunerate member farmers for milk that cannot be delivered to the processing firm. Since 2013, the Al Badre cooperative has adopted the principle of paying its farmer members for the volumes of milk containing antibiotic residues as an incentive not to deliver it to the cooperative and hence not to spoil the quality of the remaining milk delivered to the final client (processing cooperative or company).

FIMALAIT is currently preparing a programme in collaboration with the National Office of Sanitary Security of Food Products (Office National de la Sécurité Sanitaire des produits Alimentaires - ONSSA-) to strengthen the capacities of the staff operating in milk collection centres. Some 340 collection centres out of 2550 have been identified as needing specific support to make sure that they comply with international standards. Water quality is considered to be an important issue to facilitate cleaning of the cooling tanks in the centres, and equipment is needed for milk quality analysis.

I nitiatives to improve transparency and quality testing at processing plant In several cooperatives, including Al Badre, both the top management and the members complain about the lack of transparency of the evaluation system for milk quality. In fact, the criteria used to evaluate milk quality are imposed by the dairy processor, who is the only operator with equipment for laboratory analysis, and therefore the cooperative members have no say in the definition of criteria and no way as to dispute the test results. In fact, dairy processing units use the issue of milk contamination by antibiotics to avoid collecting all the raw milk supplied by farmers. As a single batch from a farm that has treated a sick cow with antibiotics can contaminate the entire milk tank in a collection cooperative, dairy processing companies use this argument to reject raw milk, and this allows them to avoid paying farmers. Such a situation is often seen in cases of milk excesses, which leads to members of collection cooperatives having to find alternative outlets for their milk, such as informal milk markets in suburban areas, often at lower prices.

The cooperative Al Fouarate had good but short-lived experiences in controlling the processors' laboratory results using laboratory equipment provided by the processor. In 2012, the dairy processor sold to Al Fouarate a rather costly (US\$ 1 500) miniature laboratory called Milkoscan, which performed rapid routine tests on the chemical quality of raw milk. This milk quality assessment system resulted in improvements in milk traceability, allowing a rapid identification of batches with limited fat contents or inadequate solid non-fat contents. It also allowed a stabilisation of raw milk prices paid to the cooperative, as the members of the cooperative had a reliable tool to challenge the results of the tests that were carried out by the processor. However, this system came to an end when the device broke down for lack of maintenance. The cooperative could not afford to buy new equipment as advised by Centrale Danone. Also with a view to increasing traceability, the Al Fouarate cooperative purchased a Gerber centrifugation machine that determines milk fat content. However, given the complex and dangerous manipulation of chemicals such as sulphuric acid, as well as the timeconsuming analyses (more than 30 minutes for a single sample), use of this device was abandoned.

\section{FIMALAIT is also planning to create specialised accredited laboratories dedicated to milk}

quality analysis. This requires good governance and a feeling of adequate collaboration within the dairy chain. Currently, there is the intention to develop three laboratories in the most prominent regions of dairy farming in Morocco, namely Doukkala, the Gharb and the Tadla regions, which currently represent 60 percent of the national raw milk output. These regions are expected to become more prominent, as they have water availability allowing a better, sustainable development of dairy farming than in water stressed areas.

\section{Challenge 2 - Offering attractive and cost-efficient payment systems}

The liberalization trend has induced authorities to encourage private peddlers to deliver raw milk collected directly to private factories through their private collection centres. This situation creates fierce competition between cooperatives and private peddlers. As a result, the dairy sector in Morocco is characterized by a segmented supply, given the large number of small and family producers delivering small quantities of milk. This makes it difficult to introduce payment systems at farmgate level that reflect quality-based prices for milk (Sraïri, 2007). 
At the three collection cooperatives Al Moun, Al Badre and Al Fouarate, farmers are paid every 2 weeks for the raw milk they have delivered. Therefore, these cooperatives find themselves in a delicate financial situation, with treasury imbalances, as they have to advance the money to pay the suppliers (farmers) until they are paid by their clients, the dairy processing firms (in this case Centrale Danone for Al Badre and Al Fouarate and Safilait for Al Mouna). This may drive cooperatives to negotiate agreements with banks to obtain financial facilities such as overdraft authorizations. As a result, the cooperatives are confronted with weak business margins. This situation is most acute during low production periods when overheads (salaries, electricity bills, transport, procurement of material) sometimes exceed incomes from milk sales. "Business is highly seasonal" was expressed by interviewees from the Al Mouna and Al Fouarate cooperatives. Both suffer from this seasonality because they are located in areas where irrigation facilities are limited and are therefore subjected to periods of severe fodder shortages and reduced raw milk output.

Initiatives to shorten the payment period

Because private companies are required to pay taxes, whereas cooperatives are not, the price for milk paid by private peddlers is generally lower than that of the cooperatives. Nevertheless, farmers are increasingly supplying private peddlers. There are several reasons for this: private peddlers are not as demanding as cooperatives are with respect to the quality of raw milk and peddlers collect the raw milk directly from farms using pick-up trucks. Furthermore, farmers are paid on a daily basis by private peddlers instead of having to wait for two weeks when supplying a cooperative. Different payment systems are being put into place by cooperatives to reduce the delayed payment period for farmers. For instance, the Al Badre cooperative ensures rapid payment of its farmers on a regular basis at the end of each week, according to the volume of milk delivered. The cooperative has also developed the option of paying farmers through bank transfers. However, this modern payment system is not accepted by all farmer members - in the case of Al Badre and Al Mouna, the majority still prefer receiving cash.

Initiatives to provide additional services

Private peddlers collect milk with pick-up trucks from the location were the farmer has his dairy farm. To remain attractive, most cooperatives have arranged transport to collect the milk, or use private peddlers (who are sometimes also cooperative members) to do that for them.

Some cooperatives have been developing social services for their members. Al Badre cooperative for instance has managed to implement financial activities with social benefits for the whole village community. In 2008, this cooperative bought an ambulance for the village, and the cooperative built a school and a small clinic. The cooperative also initially financed a private medical insurance plan costing its members US\$ 60 per year. This medical plan unfortunately came to an end after the insurance company decided to triple the premium.

Value addition is a way for farmers to increase their income. For example, farmers from the Al Badre cooperative started a movement to transform raw milk into value-added dairy products such as mozzarella cheese. However, this initiative remained at the individual level instead of becoming a cooperative activity, as the top management of the cooperative did not manage to find a reliable client to buy the overall output of cheese on a daily basis, all year long. Contacts are still being established with restaurants located in the city of Casablanca to try to sell the daily output of mozzarella at good prices.

\subsection{Implications for the institutional environment}

In view of the two main organizational challenges that hinder the marketing capacity of the cooperatives, as well as the solutions that they found to address them, we have singled out some key findings that deserve further analysis.

\section{Coordination in the dairy chain}

The reason for not remunerating farmers who comply with quality requirements (high fat and protein contents and low microbial contamination) is the fact that the samples assessed by the dairy 
processing firms (in this case Safilait and Centrale Danone) are taken from milk pooled from all cooperative members, who form a heterogeneous group of producers. Therefore, payments to farmers are based on volumes delivered rather than on quality (Sraïri et al., 2009). For example, the Colait/Extralait dairy processing cooperative, located in the suburbs of the Kenitra city, is mainly supplied through its 91 collection centres. These centres are however tempted to deliver their supply to competing processors (i.e. Centrale Danone or COPAG), whenever Colait/Extralait tries to implement stricter controls on milk quality. Therefore, a long- term effort is underway to establish a relationship with top managers of milk collection cooperatives based on trust.

The Colait/Extralait cooperative continues to suffer from unfair competition from milk peddlers supplying the mainly informal milk processing networks, given the proximity of several important urban centres, including the conurbation of Kenitra-Salé-Rabat (population 3 million). This situation creates unfair competition with formal milk collection circuits. However, these shorter circuits seem to accommodate both farmers and consumers - farmers sell directly to small shops without having to comply with complicated procedures of quality and payment, and consumers buy milk and some traditional dairy preparations (milk fat, locally known as lben, or yogurts called raib) at lower prices from the Mahlabates. In addition, the circuits are tolerated by local authorities given the crucial social and economic roles that they play. In fact, they provide steady incomes for a large number of families.

\section{Financial instruments and capacity development programmes}

Despite some efforts by the milk collecting cooperatives to enhance milk quality and meet the requirements of the private dairy processors, in most cases the measures implemented are either costly (aluminium cans, quality testing devices) or unsustainable (devices not easy to maintain, unfair competition from informal circuits). The cooperatives' leeway in improving the milk quality of deliveries is therefore limited.

The lack of financial instruments to facilitate investments in adequate quality assurance equipment and capacity development programmes on quality-related issues acts as an impediment for these cooperatives to improve milk quality for the private processors and thereby to provide a decent quality-related remuneration for their members. Support for the cooperatives to invest in long-term, high-quality equipment is urgently needed (Sraïri, 2011).

\section{I nstitutional support for effective smallholder collective action}

The study revealed that the cooperatives perceive a lack of support on the part of the institutional environment, and in particular of current state policies vis-à-vis smallholders and their cooperatives. According to the interviewed persons, the Green Morocco Plan foresees measures for supporting collective action, but these do not sufficiently reach smallholder cooperatives. The ANEB and Al Fouarate representatives interviewed pointed out that support measures to smallholder farmer organizations allocated by the Green Morocco Plan through FIMALAIT were not sufficiently implemented. An annual budget of DH 15 million (approximately US\$ 1.5 million) has now been allocated to the dairy chain through FIMALAIT, after a 5-year delay in disbursement. Another DH 55 million/year (approximately US\$ 5.5 million/year) has been promised but not yet made available to the dairy chain operators and in particular to farmers.

FIMALAIT is planning to convene a meeting with board members to decide on how best to use the DH 15 million per year. There is a certain lack of trust within the interprofessional FIMALAIT and also towards cooperative managers. Mistrust is partly due to the unclear governance structure within FIMALAIT and the weight of farmers' representatives with regard to the dairy processing units, and unbalanced power relations between actors in the chain. The director of Centrale Danone was elected as the first president of FIMALAIT, with the support of the Ministry of Agriculture, despite ANEB's initial reservations. After convening a crisis meeting in 2013, in a context marked by soaring milk powder prices on global markets, FIMALAIT requested the national authorities to intervene through an increase in milk prices throughout the dairy chain (from farmgate to consumption). In August 2013, national authorities responded favourably to the request with price increases shared between dairy processors and dairy farmers. 
The main challenge for FIMALAIT is to allow the emergence of members capable of advocating the interests of all the actors of the dairy chain in a balanced way. FIMALAIT is currently in the process of obtaining final approval from public authorities to be recognized as the only representative body of the dairy chain in Morocco. Another challenge of this body which is expected to play a major role both at national as well as at decentralized level, is to obtain a budget that will allow it to better function. 


\section{Comparative analysis and recommendations}

In their ambition to be effective marketing organizations for their members, cooperatives face several organizational challenges related to a quality control system that induces farmers to enhance milk quality and to an effective payment scheme that aligns farmers' demand for direct payment for milk deliveries with the cooperative's need for working capital. The main research question of this report has been "What is the influence of the external environment on how dairy cooperatives deal with two organizational challenges?" The preceding chapters have shown that both in Kenya and in Morocco, the answer to the main research question is not straightforward, as the characteristics and strategies of the various cooperatives differ. In addition, the two countries, while having some commonalities, are quite different in terms of the extent and type of support dairy cooperatives receive from the institutional environment.

In order to obtain more clarity on the degree of support provided by the institutional environment to selected dairy cooperatives in Kenya and Morocco and for the sake of this comparative analysis, we have identified three broad areas: strengthening the internal organization of the cooperative sector, improving policies and public regulation, and facilitating multi-stakeholder platforms to discuss, propose and implement these enabling policies. For each of these three issues, some recommendations are suggested to policy makers to improve the institutional environment for dairy cooperatives in Kenya and Morocco.

\subsection{Cooperative strengthening and self-organization}

The case studies showed that dairy cooperatives in Kenya and Morocco are quite different in their activities, organization and role in the value chain. For instance, in Morocco, $65 \%$ of all milk is collected by cooperatives and processed in the formal dairy chain. In Kenya, only $25 \%$ of all milk goes into the formal chain, with cooperatives accounting for the largest share of this milk handling. As to the organizational set-up, the first-tier, primary collection cooperatives in Kenya resemble the archetypical multi-purpose cooperative, which provides multiple services to its members, thereby creating commitment. Kenyan dairy cooperatives handle milk only from their members. Although the system is not perfect, as the 50 -litre aluminium milk can is sometimes filled with milk from different farmers in the village, the formal value chain for processed milk is in a good starting position to address the necessary quality improvement.

The primary cooperatives in Morocco, however, do not have clear user-boundaries, as they may handle milk from members acting as 'peddlers', collecting milk from other members and non-members alike, as well as from other informal peddlers. This practice of buying from multiple suppliers, who often collect milk from different farmers in one container, limits traceability and quality control and weakens farmer loyalty and their willingness to invest in their cooperative.

Currently, in both countries, cooperative milk collection centres represent suitable organizations to provide technical support to dairy farmers, given their geographic and human proximity to farmers. This is especially important for farmers who own high-productivity breeds, as they need adequate knowledge on feed formulation and hygienic practices for a higher milk yield and quality. However, the key question is, who is to pay for this technical assistance? Farmers are only willing to pay for this support if it clearly leads to a higher income, from selling more volume or higher quality. If cooperatives, as service providers to their members, finance the support activities from their own budget, they need either to charge their members individually or they need to retain a part of the milk payment for this purpose. In Kenya, a promising development is the establishment of dairy hubs that provide training services and inputs to dairy farmers. These hubs are the outcome of a strategy developed by the Kenyan Government, donors (the Gates Foundation) and development NGOs (notably Heifer International) and a number of other partners. The cooperatives we studied illustrate 
the scale and level of service provision that these hubs may provide. In Morocco, such a dairy hub development would need more time to be established. I nitially, the existing primary cooperatives would need to strengthen their internal organizational capacities and efficiency as well as the quality of their bulking services. Whereas Kenyan dairy cooperatives and hubs work with dedicated processing partners, the weaker internal coordination and transparency in the dairy chain in Morocco makes it less likely that the processing industry will invest in technical upgrading of primary cooperatives.

\subsection{Public support and regulation}

Evidence and experience show that public support and regulation are often needed for cooperatives to be established and to become legitimate organizations. Public support may include subsidies and fiscal incentives, education, training and special community activities (Gijselinckx and Bussels, 2014).

However, interventionist approaches often create dependencies upon external agents, at the expense of autonomy, empowerment, social cohesion and financial responsibility (Thorp et al., 2005). Therefore, while public support may be needed in the initial phases of establishing cooperatives, they should be able to develop into autonomous organizations, to avoid long-term dependence on external aid.

Both countries show similarities in the development of institutional context, with high state involvement in the 1960-70s, which was gradually replaced by an increased role for private investments in processing in the 1980s, followed by a phase of liberalization with unregulated dairy prices from the 1990s onwards. This new institutional context leads to more complex multi-stakeholder dairy chain coordination, and to more competitive and efficient service provision by dairy cooperatives.

Government attitudes towards cooperatives and producer organizations is steadily changing in many developing and emerging economies (Bijman et al., 2016). In the case of Morocco and Kenya, dairy cooperatives are considered by the state as important agents of change. This has resulted in open debate and policies on improving the institutional environment to support these organizations.

Quality-based payment schemes are being piloted in Kenya. Given the need for close collaboration in the dairy chain and the investment and organizational demands on the collection centres, these pilots are currently led and funded by foreign donors and NGOs. Theoretically, final milk processors could pay premiums for good-quality milk, and invest this in order to help primary cooperatives improve the testing of milk deliveries. Quality-based payment to the supplying cooperative is one important step to increase the quality of the raw milk used for processing. In Morocco, the share of milk that is channelled through the processing industry is much larger than in Kenya. This creates better starting points to establish quality-based payment systems by processors to the primary cooperatives. But to become really effective for quality enhancement, the primary cooperatives would need to make individual payments for milk deliveries, as group deliveries continue to allow free-riding behaviour by group members. Here, again, the issue of the cost of milk quality testing remains an important hurdle.

The government could play an important role in facilitating the necessary investments in reliable instruments for decentralized quality testing at the milk collection points. Primary cooperatives are not able to solve the problem of low quality individually, because quality testing equipment is expensive. Because members have alternative options to sell their milk, it is unlikely that a majority of them would agree on investments in such equipment. This problem can only be solved with investment by the processors, enforced by state regulations on minimum milk quality and compulsory quality testing. Both in Kenya and Morocco, the state can play an important role in milk quality enhancement by setting minimum standards, controlling compliance and sanctioning non-complying actors. Improving quality control together with raising dairy productivity should be part of the overall incentives to benefit breeder associations and dairy research institutes. 


\subsection{Public-private policy dialogues}

Both quality improvement and the introduction of fair and efficient payment schemes may need closer collaboration between public and private partners in the dairy industry- not only to improve information exchange, but also because some regulation may be needed to help the sector solve problems of collective action. Regulations may be issued by the state or by a public-private organization having sufficient authority in the industry. By facilitating the creation of a platform for professional organizations and agricultural cooperatives to discuss policies, the government can support the development of much-needed networking and collaboration.

In Kenya, the cooperative sector is based on a strong network of first- and second-tier cooperatives, which have developed links with private processors and policy-makers. A strong coordinating role is played by the Kenyan Dairy Board, which represents all major private and public actors of the dairy value chains. In Morocco, links between dairy cooperatives, dairy processing companies and the government are only just starting to form. A promising development is the recent establishment of the interprofessional platform, FIMALAIT, to design appropriate dairy policies, and act as a mobiliser of investment support to address the milk quality challenges. In the end, good collaboration among the state, farmer organizations, private companies and NGOs, could lead to a more "pro-active role in overcoming market constraints to achieve pro-poor agricultural growth" (Ortmann and King, 2007).

\subsection{Recommendations for an enabling institutional environment}

In both countries, the change in the dairy landscape following the liberalization of the dairy markets in the 1980s represents a an opportunity to redefine not only the roles of the various actors along the chain but also the role of the state in achieving a more equitable distribution of benefits. The state can perform a strategic and facilitation role by presenting a strategic vision of dairy development, stimulating coordination between public and private actors in the dairy industry, and presenting clear regulations on milk quality and fair payment schemes. Table 7 lists the main challenges and initiatives that we documented in the case study research. Below, we recommend policies and institutional arrangements that could help the cooperatives to develop more effective initiatives.

Improve awareness of quality at consumer level

Informing consumers about the nutritional quality of dairy products can be done by public-private collaboration in information campaigns and special support programmes such as school nutrition campaigns. As processed and packed milk is more expensive than fresh milk, a large majority of poor consumers choose unprocessed fresh milk, despite the potential food safety risks and the need to boil the milk before consumption. It is therefore the joint responsibility of public authorities and the private sector to lower the price of dairy products for consumers and at the same time provide food safety assurance.

Improve quality at farm level

To improve milk quality at farm level, the farmer needs to obtain skills and resources in the form of education, training and technical assistance. There is an important role in this for public extension services, and/or the cooperatives themselves, with financial support from the state. In Morocco, this arrangement would be in line with the Green Morocco Plan and within the mandate of the interprofessional organization, FIMALAIT. 
Table 7 Comparing the main initiatives that resulted from the case studies

\begin{tabular}{|c|c|c|}
\hline Che & Main initiatives in Kenya & Main initiatives in Morocco \\
\hline $\begin{array}{l}\text { Effective } \\
\text { and efficient } \\
\text { quality } \\
\text { assurance } \\
\text { systems }\end{array}$ & $\begin{array}{l}\text { Improve awareness of quality at consumer level: } \\
\text { - Improve regulation to uphold standards } \\
\text { - 'Milk ATMs' to sell unpackaged processed milk } \\
\text { Improve quality at farm level: } \\
\text { - Increase frequency of collection (twice a day) } \\
\text { - Impromptu checks by quality assurance team } \\
\text { - Social control by observer farmers } \\
\text { - Train farmers in milk handling and storage } \\
\text { - Apply preventive antibiotics to the herd in shifts } \\
\text { - Restrict cooperative membership to 'serious } \\
\text { farmers' } \\
\text { Improve quality and traceability at collection centre: } \\
\text { - Require use of aluminium containers } \\
\text { - Apply strong sanctions on adulteration } \\
\text { - Pay graders to apply control tests } \\
\text { Improve transparency and quality testing at } \\
\text { processing plant: }\end{array}$ & $\begin{array}{l}\text { Improve awareness of quality at consumer level: } \\
\text { - Coordinated media campaigns } \\
\text { Improve quality at farm level: } \\
\text { - Boost capacity development programmes and } \\
\text { infrastructure. } \\
\text { - Fine fraudulent behaviour as part of rules and } \\
\text { procedures; } \\
\text { - Increase frequency of milk collection } \\
\text { - Use aluminium cans to transport milk } \\
\text { Improve quality and traceability at collection centre: } \\
\text { - Separate peddler-provided milk } \\
\text { - Improve cleaning of cooling tanks } \\
\text { - Payment of contaminated milk from the } \\
\text { cooperative to farmers as an incentive not to } \\
\text { - deliver it to the client processor. } \\
\text { - Investments in quality control devices } \\
\text { - Regular testing of raw milk density } \\
\text { Improve transparency in quality testing at processing } \\
\text { for quality testing }\end{array}$ \\
\hline $\begin{array}{l}\text { Attractive } \\
\text { and cost- } \\
\text { efficient } \\
\text { payment } \\
\text { systems }\end{array}$ & $\begin{array}{l}\text { Shortening the payment period: } \\
\text { - Emergency payment facilities } \\
\text { - SACCO / bank transfers } \\
\text { - Use reserve funds } \\
\text { - M-Pesa transfers to farmers } \\
\text { Provision of additional services by cooperative: } \\
\text { - Transport } \\
\text { - Check-off system for inputs and consumer goods } \\
\text { - } \text { (store) } \\
\text { - Health insurance payments } \\
\text { - Link to bank loans (SACCO) } \\
\text { - Annual bonus based on quantity of milk delivered } \\
\text { - Developing product value addition } \\
\text { Increase member commitment } \\
\text { - Gender-sensitive payment } \\
\text { - Transparency, and rejuvenating leadership } \\
\text { - Sell shares to raise funds for investments in } \\
\text { infrastructure }\end{array}$ & $\begin{array}{l}\text { Shortening the payment period: } \\
\text { - Rapid payment system in cash or bank transfer } \\
\text { - Increase bankability of farmers } \\
\text { Provision of additional services as cooperative: } \\
\text { - Provide transport to collect the milk on the farm } \\
\text { - Finance social protection services } \\
\text { - Develop product value addition } \\
\text { Increase member commitment: } \\
\text { - Reduce the incidence of private peddlers in milk } \\
\text { deliveries }\end{array}$ \\
\hline
\end{tabular}

Dedicated capacity-building programmes can be funded by the sector itself. For instance, the state could introduce a levy on all milk deliveries to the processors (or on all sales of processed milk products) to provide funding. The latter would imply that the industry pays for the extension services, but that the state acts as an intermediary, with regulations to manage the free-rider problem.

Technical training programmes related to improving quality should be integrated in more general livestock enhancement programmes that include fodder usage, veterinary care and herd improvement. As these elements are likely to be provided by different companies or NGOs, there is a need for 
coordination among all these business service providers. A public-private partnership organization could take up this coordination task.

While farmers need to be enabled to improve the quality of the milk they deliver, they should also receive clear incentives that induce them to deliver better quality milk, e.g. by a quality-based payment system.

Improve quality and traceability at collection centre

From our investigation, it became clear that developing and implementing quality testing to facilitate quality-based payment systems are typically the tasks of public-private partnerships, as state regulation and financial support must go hand-in-hand with strict agreements both among cooperatives (better horizontal coordination) and between cooperatives and private milk processors (better vertical coordination).

One of the most salient issues in the Moroccan dairy industry is the dispersed cooperative landscape, with a large number of very small milk collection cooperatives in which not all milk is supplied by members. The state should induce farmers to have their small cooperatives merge into larger ones, thereby increasing the efficiency of their operations. While the decision to remain independent or to merge with another cooperative is a decision to be taken by the cooperatives themselves, the state can provide support for mergers in the form of managerial assistance, legal advice, and investment subsidies in case a new and larger collection centre has to be built.

Also on the issue of traceability and quality assurance, the state has an important role in coordinating the various public and private actors involved, preventing free riding and enacting food quality policies that set clear standards, while at the same time controling compliance and applying sanctions in case of violation.

I mprove transparency and quality testing at processing plant Quality testing always implies information asymmetry between buyer and seller, both within cooperatives and between cooperatives and the processing plants. As it is in the interest of almost all actors in the dairy industry to have clear quality standards, the state can support the credibility and transparency of quality testing, establishing accredited quality testing laboratories and facilitating public-private platforms for discussions between cooperatives and processors on quality criteria and measurement routines.

\section{Shortening the payment period}

The state can induce dairy processors to pay dairy cooperatives immediately upon delivery of the milk, so the latter can pay their members in a timely way. Furthermore, the state can facilitate credit provisioning by banks to shorten the payment period for milk supplied to the cooperatives. In many countries, cooperative (agricultural) banks are subsidized by the state, on the pretext that low-cost loans are a crucial ingredient for rural development. The state could also reduce the risk that private sector banks face when dealing with dairy farmers and cooperatives by offering low-interest funds for financial products targeted to dairy development, or guarantee funds for working-capital loans to cooperatives.

Provision of additional services by cooperative Setting up value-adding activities may be an attractive way to generate additional income for a cooperative and thereby for its members. Ideally, such activities are paid from member investments. However, such investments are not possible for most farmers. Financial support from donor organizations, NGOs and the state could solve this problem, but only on condition that the cooperative has a good long-term business plan showing that the value-adding activities can become economically sustainable on their own.

The decision to provide additional services by the cooperatives is always subject to much debate among the members, but also among supporting organizations and policy makers. On the one hand, the provision of additional services can lead to higher member commitment and loyalty. In addition, it can solve some of the information and coordination problems that farmers face when choosing 
suppliers of feed, veterinary services, technical assistance, transport and credit. On the other hand, the more economic activities the cooperative carries out, the more diverse the management skills that are needed on the part of the cooperative leaders and the more risk the cooperative faces (as all activities require some kind of investment which may not be fully regained). Another challenge is that not all members may benefit equally from these additional services, which may lead to difficult decision-making processes in the General Assembly and Board of Directors. Our advice would be to provide only those services that directly relate to the core activities of the cooperative. In addition, cooperatives may enter into strategic alliances with other service suppliers, which would also generate the benefit of coordination but does not entail high risks for the cooperative itself.

Increase member commitment

A lack of renewal of the board often leads to reduced member commitment. Providing education and training on cooperative governance can also enhance participation and thereby commitment. Finally, the state may induce cooperatives to increase transparency within the cooperative as well as to rejuvenate the leadership. For example, the state may introduce clear rules on the composition of the board of directors, particularly the time individual board members can stay in office.

Given that a large share of smallholder farmers are women, but that they often have fewer rights than men both within and outside the cooperative, more attention for gender issues is needed from the state as well as from public-private partnerships that coordinate dairy development programmes. For instance, we documented an interesting experience in Kenya, where one cooperative alternated payment for morning and evening milk to the man and the woman in each household.

Whereas membership of cooperatives is a purely private decision on the part of farmers, state agencies could help cooperatives to make cooperative membership more socially and economically attractive. This can be done by information campaigns but also by choosing cooperatives as main suppliers of institutional purchases. 


\section{References and websites}

Abdulai, A. \& Birachi, E.A.2009. Choice of Coordination Mechanism in the Kenyan Fresh Milk Supply Chain. Appl. Econ. Perspect. P, 31(1): 103-121.

Agarwal, A. 2001. Common property institutions and sustainable governance of resources. World Dev., 29(10): 1649-1672.

Biénabe, E. \& Sautier, D. 2005. The role of small scale producers' organizations to address market access. Paper presented at the International Seminar: Beyond Agriculture: Making Markets Work for the Poor. London.

Bijman, J., Iliopoulos, C., Poppe, K.J., Gijselinckx, C., Hagedorn, K., Hanisch, M., Hendrikse, G.W.J., Olliia, P., Pyykkönen, P. 2012. Support for Farmers' Cooperatives. Final Report European Commission, Brussels.

Bijman, J., Muradian, R. \& Schuurman, J. 2016. Cooperatives, economic democratization and rural development. Cheltenham, UK, Edward Elgar Publishing.

Birachi, E.A. 2006. Determinants of coordination and supply chain performance: The case of fresh milk supply chains in Kenya. Christian-Albrechts Universität, Kiel, Germany. (PhD-dissertation)

Coleman, J.S. 1988. Social capital in the creation of human capital. Am. J. Soc.: S95-S120.

Dorward, A., Poole, N., Morrison, J., Kydd, J. \& Urey, I. 2003.Markets, institutions and technology: Missing links in livelihoods analysis. Dev. Policy Rev., 21(3): 319-332.

Fama, E.F. \& Jensen, M.C. 1983. Agency problems and residual claims. J. Law Econ., 26(2): 327-349.

Foreman, I. \& de Leeuw, B. 2012. Quality Based Milk Payment Study. Nairobi, SNV.

Gijselinckx, C. \& Bussels, M. 2014. Farmers cooperatives in Europe: Social and historical determinants of cooperative membership in agriculture. Ann. Public Coop. Econ., 85(4): 509-530.

Herbel, D. \& Ourabah Haddad, N. 2012. Successful farmer collective action to integrate food production into value chains. Food Chain, 2(2): 164-182.

Hoekstra, A.Y. 2012. The hidden water resource use behind meat and dairy. Anim. Front., 2(2): 3-8.

Kirezieva, K., Bijman, J., Jacxsens, L. \& Luning, P.A. 2016. The role of cooperatives in food safety management of fresh produce chains: Case studies in four strawberry cooperatives. Food Control, 62: 299-308.

Leana, C.R. \& Van Buren, H.J. 1999. Organizational Social Capital and Employment Practices. The Acad. Manage. rev., 24(3): 538-555.

Luning, P., Kirezieva, K., Hagelaar, G., Rovira, J., Uyttendaele, M. \& Jacxsens, L. 2015. Performance assessment of food safety management systems in animal-based food companies in view of their context characteristics: a European study. Food Control, 49: 11-22.

Makoni, N., Redda, T., van der Lee, J., Mwai, R. \& van der Zijpp, A. 2014. White gold: Opportunities for dairy sector development collaboration in East Africa. Wageningen, The Netherlands, Centre for Development Innovation Wageningen UR. 
Markelova, H. \& Mwangi, E. 2010. Collective action for smallholder market access: Evidence and implications for Africa. Rev. Policy Res., 27(5): 621-640.

Mendoza, M. \& Ton, G. 2003. Manual de procedimientos jurídicos y tributarios para organizaciones económicas campesinas. Sucre, Bolivia, CIOEC-SNV.

Mujawamariya, G., D'Haese, M. \& Speelman, S. 2013. Exploring double side-selling in cooperatives, case study of four coffee cooperatives in Rwanda. Food Policy, 39: 72-83.

Muriuki, H. 2011. Dairy development in Kenya. Food and Agriculture Organization, Rome.

Ndungu, T.W., Muliro, P.S., Omwamba, M., Oosterwijk, G. \& Jansen, A. 2016. Quality control of raw milk in the smallholder collection and bulking enterprises in Nakuru and Nyandarua Counties, Kenya. Afr. J. of Food Sci., 10(5): 70-78.

North, D.C. 1990. Institutions, Institutional Change and Economic Performance. Cambridge University Press. Cambridge.

Omiti, J. \& Muma, M. 2000. Policy and institutional strategies to commercialise the dairy sector in Kenya. Institute of Policy Analysis and Research. Nairobi

Ortmann, G.F. \& King, R.P. 2007. Agricultural cooperatives I: History, theory and problems. Agrekon, 46(1): $18-46$.

Ostrom, E. 1996. Social Capital, Self-Organization and Development. United States Agency for International Development. Washington.

Ostrom, E. \& Ahn, T.-K. (Eds.). 2009. The meaning of social capital and its link to collective action. Cheltenham: Edward Elgar Publishing.

Pei, X., Tandon, A., Alldrick, A., Giorgi, L., Huang, W. \& Yang, R. 2011. The China melamine milk scandal and its implications for food safety regulation. Food Policy, 36(3): 412-420.

Penrose-Buckley, C. 2007. Producer Organisations: a guide to developing collective rural enterprises. London, OXFAM.

Republic of Kenya. 2013. The national dairy development policy: towards a competitive and sustainable dairy industry for economic growth in the 21st century and beyond. Sessional Paper No. 5. Ministry of Agriculture, Livestock adn Fisheries. Nairobi.

Sraïri, M., Benjelloun, R., Karrou, M., Ates, S. \& Kuper, M. 2016. Biophysical and economic water productivity of dual-purpose cattle farming. Animal, 10(02): 283-291.

Sraïri, M.T. \& Chohin Kuper, A. 2007. Conséquences de la libéralisation des marchés sur les opérateurs de la filière laitière au Maroc. Rev. Elev. Med. Vet. Pays 60(1-4): 177-187.

Sraïri, M.T. 2011. Dairy development in Morocco. Rome, FAO.

Sraïri, M.T., Benhouda, H., Kuper, M. \& Le Gal, P. 2009. Effect of cattle management practices on raw milk quality on farms operating in a two-stage dairy chain. Trop. Anim. Health Pro., 41(2): 259-272.

Sraïri, M.T., Benyoucef, M.T. \& Kraiem, K. 2013. The dairy chains in North Africa (Algeria, Morocco and Tunisia): from self sufficiency options to food dependency? Springer Plus, 2(1): 1.

Thorp, R., Stewart, F. \& Heyer, A. 2005. When and how far is group formation a route out of chronic poverty? World Dev., 33(6): 907. 
Ton, G. 2010. Resolving the challenges of collective marketing: incentive structures that reduce the tensions between members and their group, ESFIM Policy Brief \#4. Wageningen, The Netherlands, ESFIM.

Ton, G. 2015. Measuring tensions and intentions: Mixing methods in the impact evaluation of development support to farmer organisations. Wageningen University, Wageningen, The Netherlands. (PhD dissertation)

Tuei, B.C. 2010. Milk Quality Control And Regulation In Dairy Production: A Case Of Dairy Producers In Kikuyu Division, Kabete District, Central Province-Kenya. Poster presented at the Joint 3rd African Association of Agricultural Economists (AAAE) and 48th Agricultural Economists Association of South Africa (AEASA) Conference September 19-23, 2010. Cape Town.

Wambugu, S., Kirimi, L. \& Opiyo, J. 2011. Productivity trends and performance of dairy farming in Kenya. Tegemeo Institute of Agricultural Policy and Development. Egerton University. Nairobi.

World Bank. 2012. World development Report 2012: Gender equality and development: World Bank Washington DC. 

Wageningen Eonomic Research P.O. Box 29703

2502 LS The Hague

The Netherlands

T +31 (0)703358330

E communications.ssg@wur.nl

www. wur, eu/economic-research

Wageningen Economic Research REPORT

2016-088
The mission of Wageningen University and Research is "To explore the potential of nature to improve the quality of life". Under the banner Wageningen University \& Research, Wageningen University and the specialised research institutes of the Wageningen Research Foundation have joined forces in contributing to finding solutions to important questions in the domain of healthy food and living environment. With its roughly 30 branches, 5,000 employees and 10,000 students, Wageningen University \& Research is one of the leading organisations in its domain. The unique Wageningen approach lies in its integrated approach to issues and the collaboration between different disciplines. 



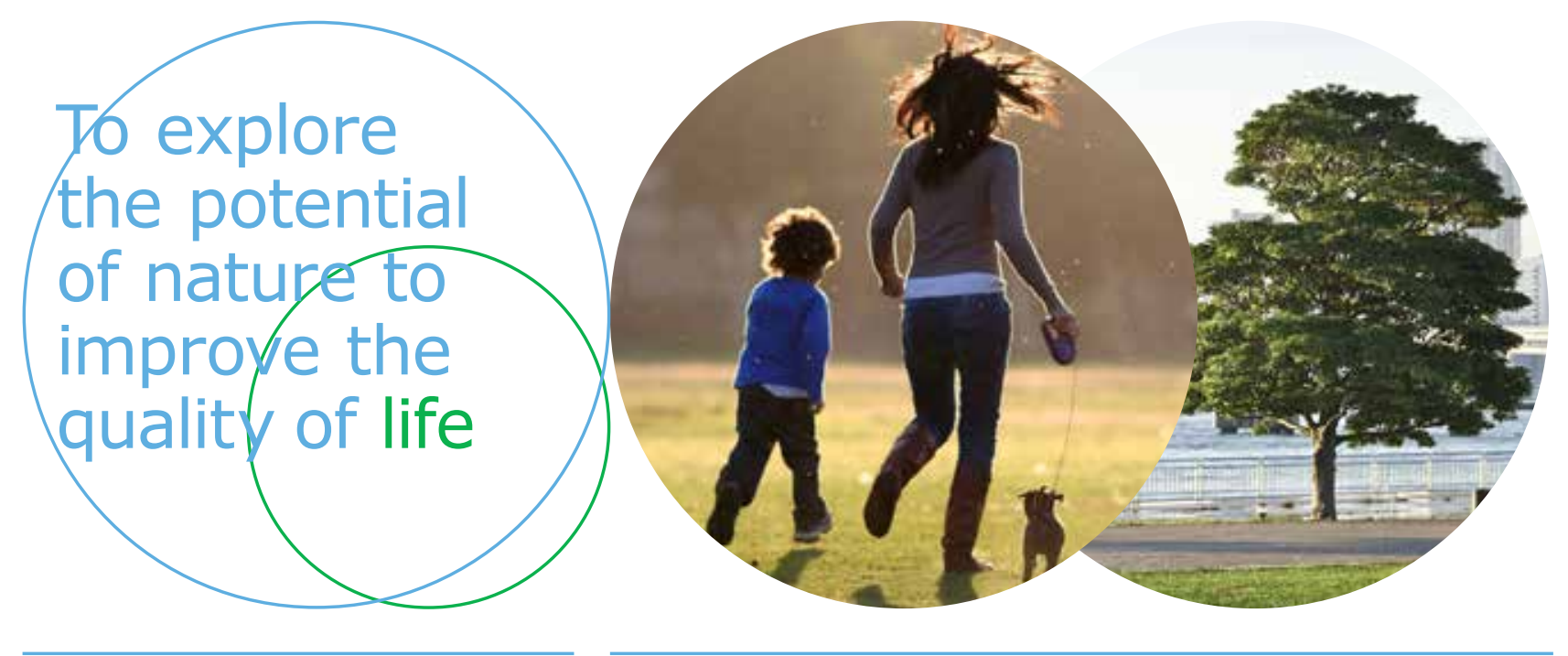

Wageningen Economic Research P.O. Box 29703

2502 LS Den Haag

The Netherlands

E communications.ssg@wur.nl

www.wur.eu/economic-research

Report 2016-088

ISBN 978-94-6343-031-9
The mission of Wageningen University and Research is "To explore the potential of nature to improve the quality of life". Under the banner Wageningen University \& Research, Wageningen University and the specialised research institutes of the Wageningen Research Foundation have joined forces in contributing to inding solutions to important questions in the domain of healthy food and living environment. With its roughly 30 branches, 5,000 employees and 10,000 students, Wageningen University \& Research is one of the leading organisations in its domain. The unique Wageningen approach lies in its integrated approach to issues and the collaboration between different disciplines.

ISBN 978-92-5-109579-9
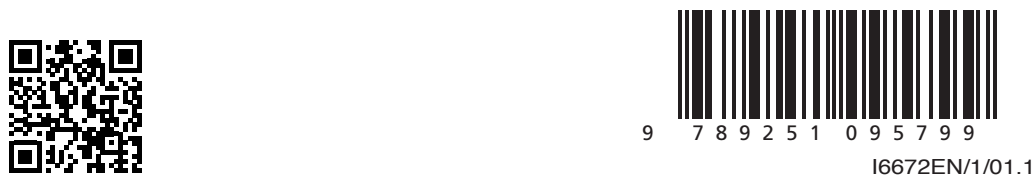
